\title{
SHALLOW STRATIGRAPHIC EVIDENCE OF SUBSIDENCE AND FAULTING INDUCED BY HYDROCARBON PRODUCTION IN COASTAL SOUTHEAST TEXAS
}

Robert A. Morton, Noreen A. Purcell, and Russell L. Peterson

U.S. Geological Survey

Center for Coastal and Regional Marine Studies

St. Petersburg, FI. 33701

Open File Report 01-274 


\section{TABLE OF CONTENTS}

SUMMARY

INTRODUCTION

SUBSURFACE GEOLOGY AND PRODUCTION HISTORIES ......................................... 4

Port Neches Field ....................................................................................................... 4

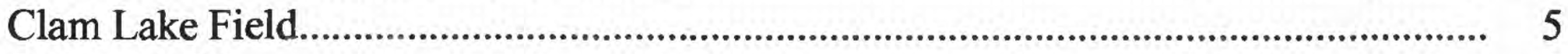

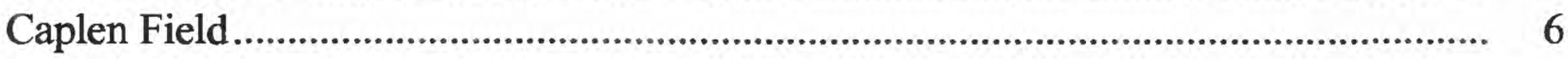

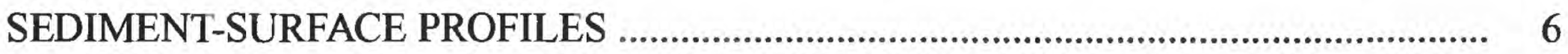

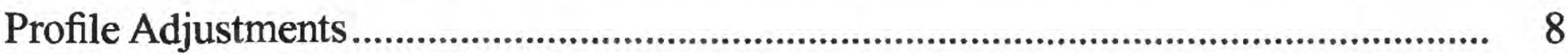

Profile Descriptions................................................................................................... 9

Estimating Open-Water Accommodation Space.................................................... 11

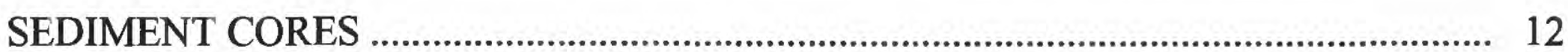

Core Descriptions and Sediment Types ..................................................................... 13

Stratigraphic Correlations and Subsidence-Erosion Calculations ................................. 14

Historical and Geological Subsidence Rates ............................................................ 15

DISCUSSION OF RESULTS ..................................................................................... 16

Subsidence versus Marsh Erosion ....................................................................... 16

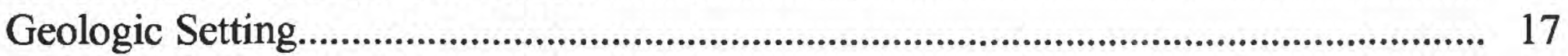

Production Characteristics ....................................................................................... 17

COASTAL ENVIRONMENTAL IMPLICATIONS _................................................... 17

ACKNOWLEDGMENTS............................................................................................ 18

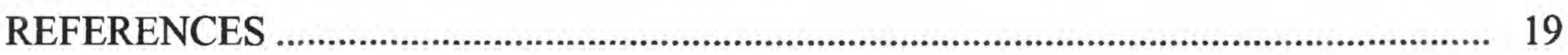

APPENDIX A: SEDIMENT-SURFACE PROFILES ........................................................... 22

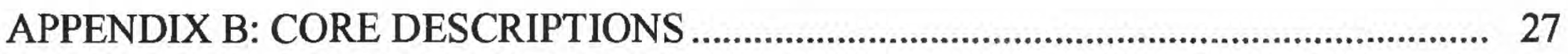




\section{SUMMARY}

Wetland losses and their progressive conversion to open water around producing oil and gas fields in the Gulf Coast region have been attributed to a variety of natural and anthropogenic processes. Three large, mature hydrocarbon fields in coastal southeast Texas were examined to evaluate competing hypotheses of wetland losses and to characterize subaerial and submerged surfaces near reactivated faults and zones of subsidence. Topographic and bathymetric profiles at the Port Neches, Clam Lake, and Caplen Fields and shallow cores at the Port Neches and Caplen Fields provide a basis for distinguishing between (1) extensive land-surface subsidence without significant subaqueous erosion, and (2) localized minor subsidence near faults accompanied by extensive subaqueous erosion. Subaqueous erosion results from submergence of wetlands, current and wave excavation of surface sediments and organic detritus, and exportation of the eroded sediments through adjacent water bodies with swift currents such as navigation channels.

Geologic settings and responses to induced subsidence and fault reactivation are different at each field site. Detailed stratigraphic correlations of sediment cores show that at Port Neches, subsidence of 35 to $90 \mathrm{~cm}$ and minor marsh erosion $(20$ to $35 \mathrm{~cm}$ ) created more than 15 million $\mathrm{m}^{3}$ of accommodation space in a nearly circular pattern over the field. At Caplen the marsh surface subsided only about $4 \mathrm{~cm}$, but the surface eroded 30 to $40 \mathrm{~cm}$ vertically, creating about 3.5 million $\mathrm{m}^{3}$ of accommodation space. The breakup of wetlands and their conversion to open water appears to be in an initial stage at the Clam Lake Field. At Clam Lake, minor subsidence along a fault is submerging the marsh plants that will weaken and eventually die either as a result of water logging or salt-water intrusion.

The different surficial responses and wetland losses at each field are also related to the primary type and rate of hydrocarbon production. The greatest land-surface subsidence occurred at the Port Neches Field where a large volume of gas was produced rapidly. At the Caplen Field, both oil and gas were produced in significant quantities and there was a period of accelerated gas production. The wetland loss, which coincided with the rapid production phase, was controlled by fault reactivation and subsequent marsh erosion. Oil was the primary hydrocarbon produced at the Clam Lake Field where a reactivated fault is responsible for the observed wetland loss. Results from this study show that although the absolute magnitude of induced subsidence may be less than $1 \mathrm{~m}$, even a minor reduction in land elevation is sufficient to initiate marsh degradation that quickly results in major wetland losses. 


\section{INTRODUCTION}

Scarps of active faults and zones of land-surface subsidence have been identified around a number of hydrocarbon-producing fields in the Gulf Coast region (Pratt and Johnson, 1926; Kreitler, 1978; Holzer and Bluntzer, 1984). The causal links between surficial topographic alterations and deep subsurface hydrocarbon production have been inferred primarily on the basis of rapid wetland changes near oil and gas fields during the period of production (White and Tremblay, 1995; White and Morton, 1997). Despite decades of observational evidence suggesting a causal relation between hydrocarbon production and wetland changes, there have been no prior quantitative studies of the topography, ecological conditions, and shallow stratigraphy across fault planes or boundaries between wetlands and open water where subsidence is suspected. To fill this data gap, reconnaissance ground surveys and detailed site observations and measurements were made at selected producing fields in coastal southeast Texas where wetland changes were attributed to subsidence and fault reactivation (White and Morton, 1997). These ground surveys involved measuring elevation differences between the upthrown and downthrown sides of reactivated faults, profiling elevations and water depths across subsidence features, and recording significant changes in biota or soil conditions around the subsidence features and across the faults.

Wetland losses can occur around the shores of pre-existing water bodies or they can develop within the marsh interiors. Wetland losses along the margins of bays and lakes can result from both (1) erosion by waves and (2) inundation by a relative rise in sea level (submergence). Even in small water bodies where the fetch is limited, strong winds in the Gulf Coast region are capable of generating enough wave energy that shoreline erosion is common, and it often leads to enlargement of the water bodies. Enlargement of the water bodies can include both increased surface areas and increased water depths. The present study focuses on interior wetland losses because erosion around open-water perimeters is common even in areas where no subsidence has been documented. Submergence could be directly linked with induced subsidence but bank erosion would only be indirectly linked to subsidence through increased water depths and thus potentially greater wave energy.

There are two competing hypotheses to explain some of the major interior wetland losses around oil and gas fields in the Gulf Coast region. One hypothesis states that the observed historical changes from interior wetlands to open water are primarily a result of land-surface subsidence. If that explanation is correct, then some of the roots and organic-rich marsh sediments may be preserved and remain in place stratigraphically under the former wetland area that subsided. The second hypothesis states that erosion of organic marsh sediments is primarily responsible for the changes from interior wetlands to open water. According to this hypothesis, the marsh plants are weakened and die either as a result of water logging or salt-water intrusion (Naidoo et al., 1992). When plant density decreases, the hydrodynamic forces in the marsh begin to erode and remove the organic-rich sediments from the marsh. Once the organic sediments are in suspension, they can be exported from the marsh into adjacent channels or other water 
bodies by currents driven by tidal and meteorological processes. Neither of these two hypotheses is mutually exclusive and both subsidence and erosion are likely contributors to the wetland changes that have been observed.

Three large, mature oil and gas fields in coastal southeast Texas (Fig. 1) were selected to evaluate the competing hypotheses of wetland losses, and to characterize ground conditions near active faults and zones of subsidence. During June 2000, sediment cores were collected and topographic and bathymetric profiles were surveyed at the Caplen Field in Galveston County and the Port Neches Field in Jefferson County. Ground observations also were made and a topographic profile was surveyed at the Clam Lake Field in Jefferson County. The primary reasons for acquiring the field data were to determine how much original organic material remained at the submerged sampling sites and to determine the magnitude of subsidence and/or erosion that had occurred. Combined topographic and bathymetric profiles also were surveyed to characterize the subaerial and adjacent submerged surfaces, and to estimate the volume of accommodation space created by wetland losses at each location. Accommodation space represents the volume of open water that was created either by subsidence or erosion and replacement or removal of the surficial sediments.

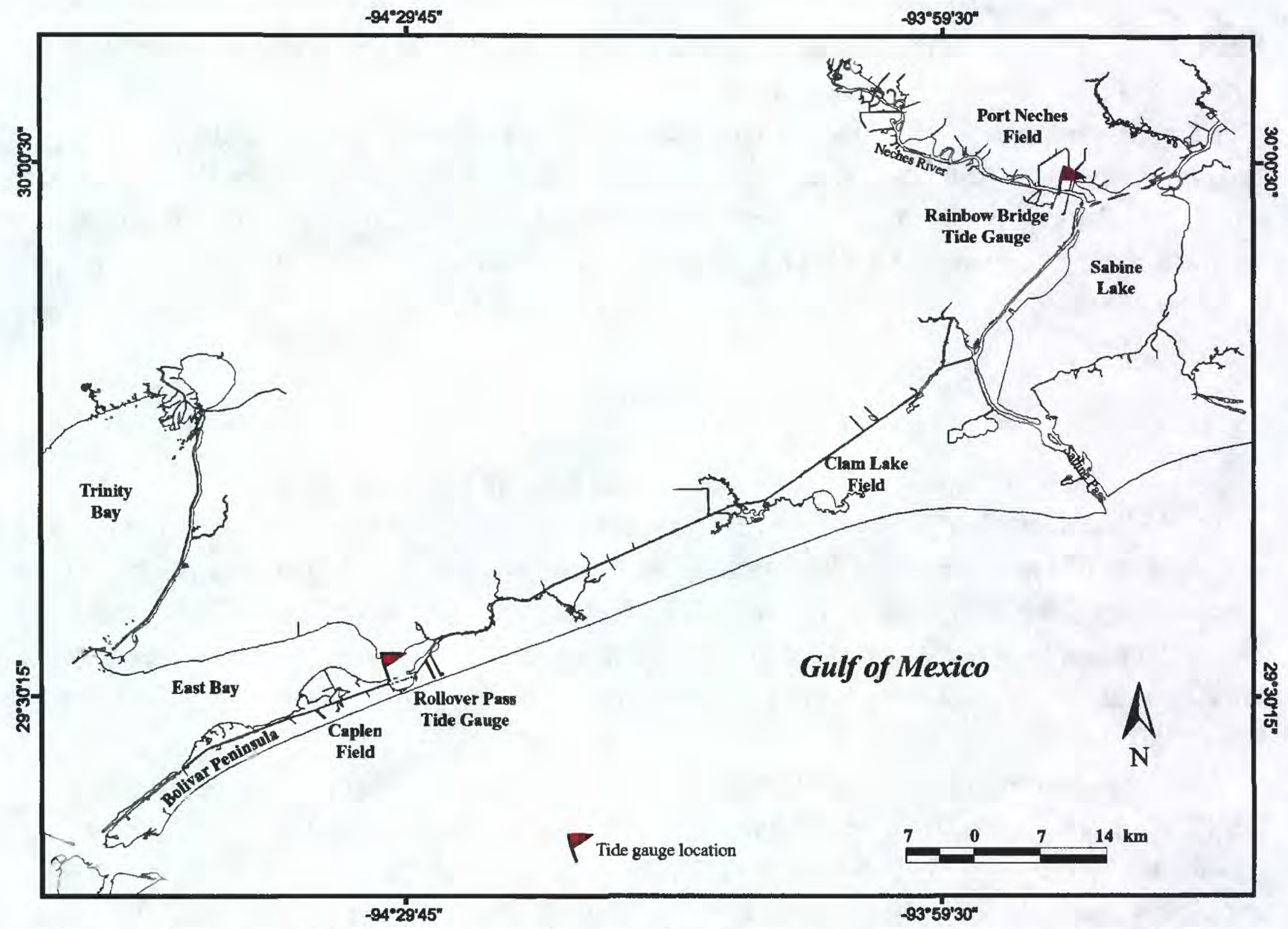

Fig. 1. Map of the southeast Texas coast showing locations of oil and gas fields and tide gauges included in this study. 


\section{SUBSURFACE GEOLOGY AND PRODUCTION HISTORIES}

Chilingarian et al. (1995) reported that young, shallow, thick, laterally extensive, uncemented, argillaceous, and highly porous geological formations are the most susceptible to subsidence induced by subsurface fluid withdrawal. These criteria apply to most of the oil and gas fields producing in the Gulf Coast region. Other important criteria involve fluid production histories for each field, the associated reduction in reservoir pore pressures, and eventually the cumulative temporal reductions in subsurface pressures over large areas. The last phenomenon is known as regional depressurization. Because formation pore pressures and horizontal stresses at the reservoir level are closely linked, decreases in pore pressure translate to increases in effective stress. The increased effective stress causes compaction of the reservoir and can reactivate faults that are critically stressed and at the threshold of failure (Wiprut and Zoback, 2000).

Kreitler et al. (1988) evaluated thousands of reservoir pressures from the Frio producing trend in Texas and demonstrated that the initial pressure gradients for many wells were far below those expected for hydrostatic (normal) conditions because of prior hydrocarbon production. Contour maps of the southeast Texas coast constructed by Kreitler et al. (1988) show the broad regional influence of subsurface depressurization that extends far beyond the limits of oil and gas production. These regional aggregated pressure-gradient observations were later confirmed by Sharp and Hill (1995), who constructed pressure-depth plots for the Big Hill and Fannett Fields within the Frio fairway of southeast Texas.

Detailed pressure histories and depletion curves are not readily available for the primary reservoirs of any of the fields included in this study. To provide a basis for comparing subsurface stress perturbations with surficial wetland changes, aggregated cumulative oil and gas production from the NRG Associates database (Table 1) was used as a gross substitute for reductions in reservoir pressure.

\section{Port Neches Field}

The Port Neches Field, also known as the Bessie Heights Field, has produced more than 46 million bbls of liquid hydrocarbons and $575 \mathrm{Bcf}$ of gas during a period of $70+$ years. The cumulative volumes of hydrocarbon production assigned to Port Neches (Table 1) include contributions from the Port Neches Field proper, as well as from North, South, and West extensions. The North extension is an area principally of gas production. Hydrocarbon production is mostly from the Oligocene lower Hackberry sands of the middle Frio stratigraphic interval at depths ranging from 2350 to $2715 \mathrm{~m}$.

Oil production at Port Neches peaked in the early 1950 s, remained relatively constant through the 1970 s, and then gradually declined in the 1980s. In contrast, gas production accelerated rapidly during the mid to late 1950s and then rapidly declined. Wetland losses began during the late 1950s, shortly after the high rates of fluid production and by 1978 more than 3400 hectares of wetlands had been converted to open water (White and Tremblay, 1995). The area of wetland 


\begin{tabular}{|l|l|l|l|}
\hline Field & Port Neches & Clam Lake & Caplen \\
\hline Discovery date & 1929 & 1937 & 1939 \\
\hline Number of wells & 110 & 55 (approx.) & 57 \\
\hline Reservoir age & Oligocene & Miocene, U. Oligocene & Miocene \\
\hline Number of prod. zones & 21 & 31 & 32 \\
\hline Production depth range & $2350-2715 \mathrm{~m}$ & $700-2045 \mathrm{~m}$ & $1220-2350 \mathrm{~m}$ \\
\hline Ave. depth of max. prod. & $2440 \mathrm{~m}$ & $1980 \mathrm{~m}$ & $2200 \mathrm{~m}$ \\
\hline Cumulative oil prod. & $34.1 \mathrm{million}$ bbls & 21.4 million bbls & 19.4 million bbls \\
\hline $\begin{array}{l}\text { Cumulative condensate } \\
\text { prod. }\end{array}$ & 12.5 million bbls & 00.1 million bbls & 00.7 million bbls \\
\hline Cumulative gas prod. & 575 Bcf & 10 Bcf & 55 Bcf \\
\hline Initial pressure gradients & Most are normal & Normal & Normal \\
\hline General field reference & Kiatta, 1986 & Williams, 1962 & Musolff, 1962 \\
\hline
\end{tabular}

Table 1. Summary of field characteristics.

loss encompassed the entire east side of the Neches River valley in a circular pattern that included the entire field and extended far beyond the limits of production. Wetland losses on the south side of the field coincided with a reactivated fault that was not visible on aerial photographs until the mid 1960s (White and Morton, 1997).

\section{Clam Lake Field}

Since 1937, the Clam Lake Field has produced more than 21 million bbls of oil and $10 \mathrm{Bcf}$ of gas (Table 1). Hydrocarbon reservoirs in the field, which are Miocene to upper Oligocene, range in depth from 700 to $2045 \mathrm{~m}$. Although hydrocarbons are encountered over a broad range of depths, most of the production is from the lower Miocene section at depths of about 1800 $\mathrm{m}$. Oil production gradually increased from the time Clam Lake Field was discovered until the late 1950 s. Between the late 1950 s and early 1960 s, oil production rapidly increased and then went into gradual decline. Gas production at Clam Lake was not significant until the late 1960s when it showed a substantial increase that lasted for about 5 years. The onset of wetland loss at Clam Lake closely corresponds to the period of accelerated hydrocarbon production. Aerial photographs show that wetlands were continuous east of the field through the mid-1950s but by the mid-1960s, surface elevations had changed and wetlands were being converted to water east and northeast of the field (White and Tremblay, 1995).

Wetland loss at the Clam Lake Field is clearly controlled by reactivation of a deep fault that is one of the principal hydrocarbon traps at the reservoir level. Fault projections by White and Morton (1997) show a close correlation between the surface expression and reservoir location 
of the fault plane. Open water in the form of coalesced ponds has replaced wetlands on the downthrown side of the fault (White and Tremblay, 1995). At the surface the fault is represented by a sharp boundary that reflects the change in elevation, surface water, and species and density of vegetation. During the field investigation, offset along the fault was not visible because the plant density during the growing season obscured the fault plane.

\section{Caplen Field}

The Caplen Field, discovered in 1939, has produced more than 20 million bbls of oil and condensate and $55 \mathrm{Bcf}$ of gas. Oil and gas reservoirs range in depth from 1220 to $2350 \mathrm{~m}$ with most of the production coming from lower Miocene sandstones at depths of about $2200 \mathrm{~m}$. Oil production at Caplen peaked in the mid-1950s but gas production was relatively insignificant until the late 1950s when it rapidly accelerated (White and Morton, 1997). High rates of gas production were sustained until the mid-1980s when they rapidly declined. Only a few wells are currently producing.

Like at the Clam Lake Field, the wetland losses at Caplen are controlled by two faults that were reactivated about 20 years after the field began producing. The intersecting surficial fault traces have the same shapes and orientations as the major subsurface faults mapped at the reservoir level (Ewing, 1985). Marshes were submerged and converted to open water along the fault traces and the loss of wetlands later extended away from the faults. The timing of wetland losses coincided with the periods of accelerated hydrocarbon production at Caplen. In the mid1950 s the faults were faintly visible on aerial photographs, but later the conversion of wetlands to open water was well defined and abrupt along the fault plane (White and Tremblay, 1995).

\section{SEDIMENT-SURFACE PROFILES}

Topographic and bathymetric profiles (Figs. 2-4, Appendix A) were surveyed independently with portable field equipment including a tripod-mounted level, graduated rod, and GPS receiver. Relative heights for ground elevations were obtained by establishing transects across the marsh at selected sites. Static GPS positions were used to determine the geographic coordinates of the start and end of each transect. In open-water areas, water depths were measured from a small boat with a graduated rod, whereas the geographic coordinates of each depth measurement were obtained with the GPS receiver. The independent topographic and bathymetric surveys were linked to construct continuous sediment-surface profiles (Figs. 5-7) by using simultaneous water-level measurements in the marsh and open water as a common datum. 


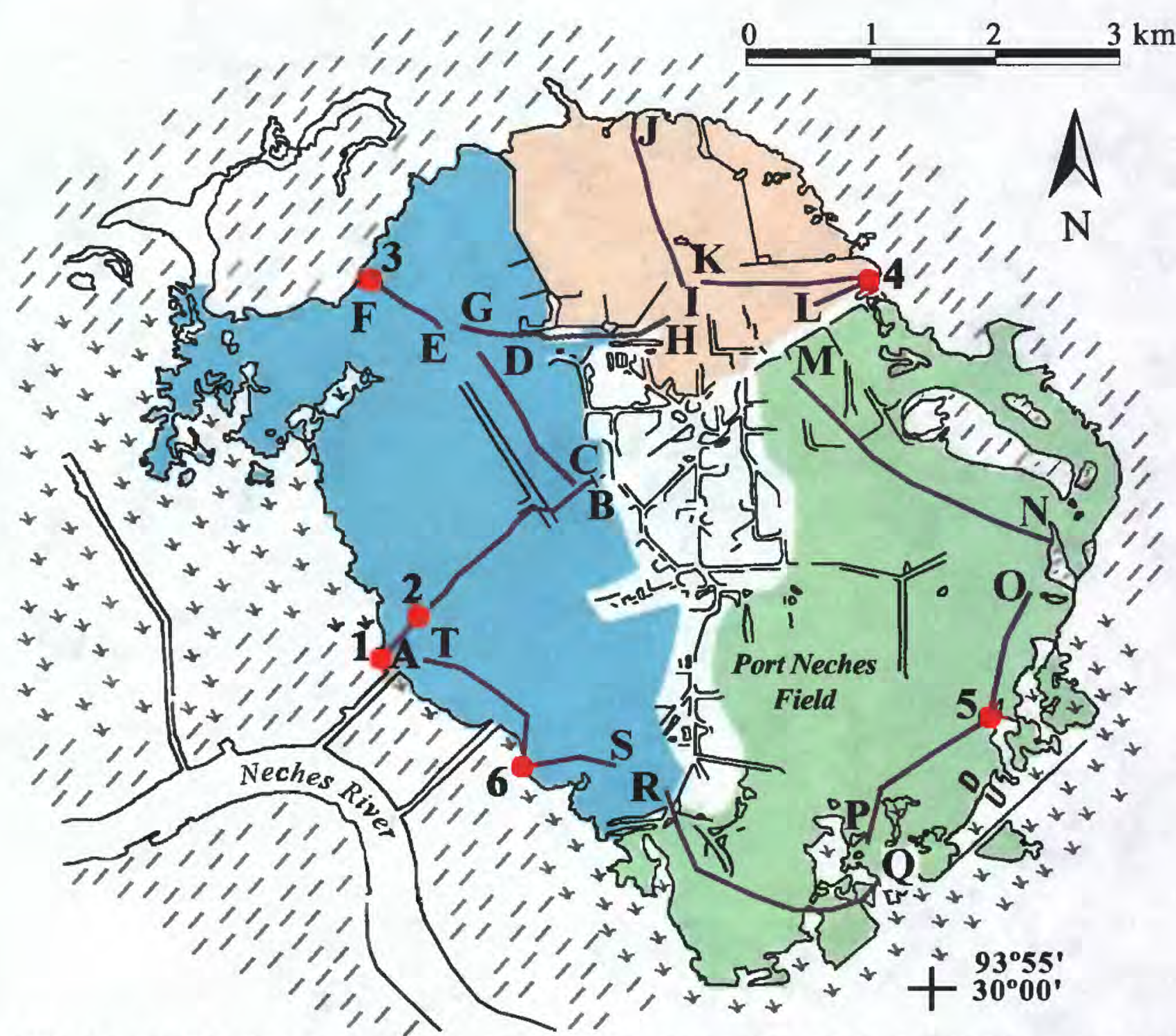

Fig. 2. Locations of shallow cores (numbers) and sediment-surface profiles (letters) surveyed at the Port Neches Field. Also shown in color are the three areas used to calculate accommodation space created by subsidence and erosion.

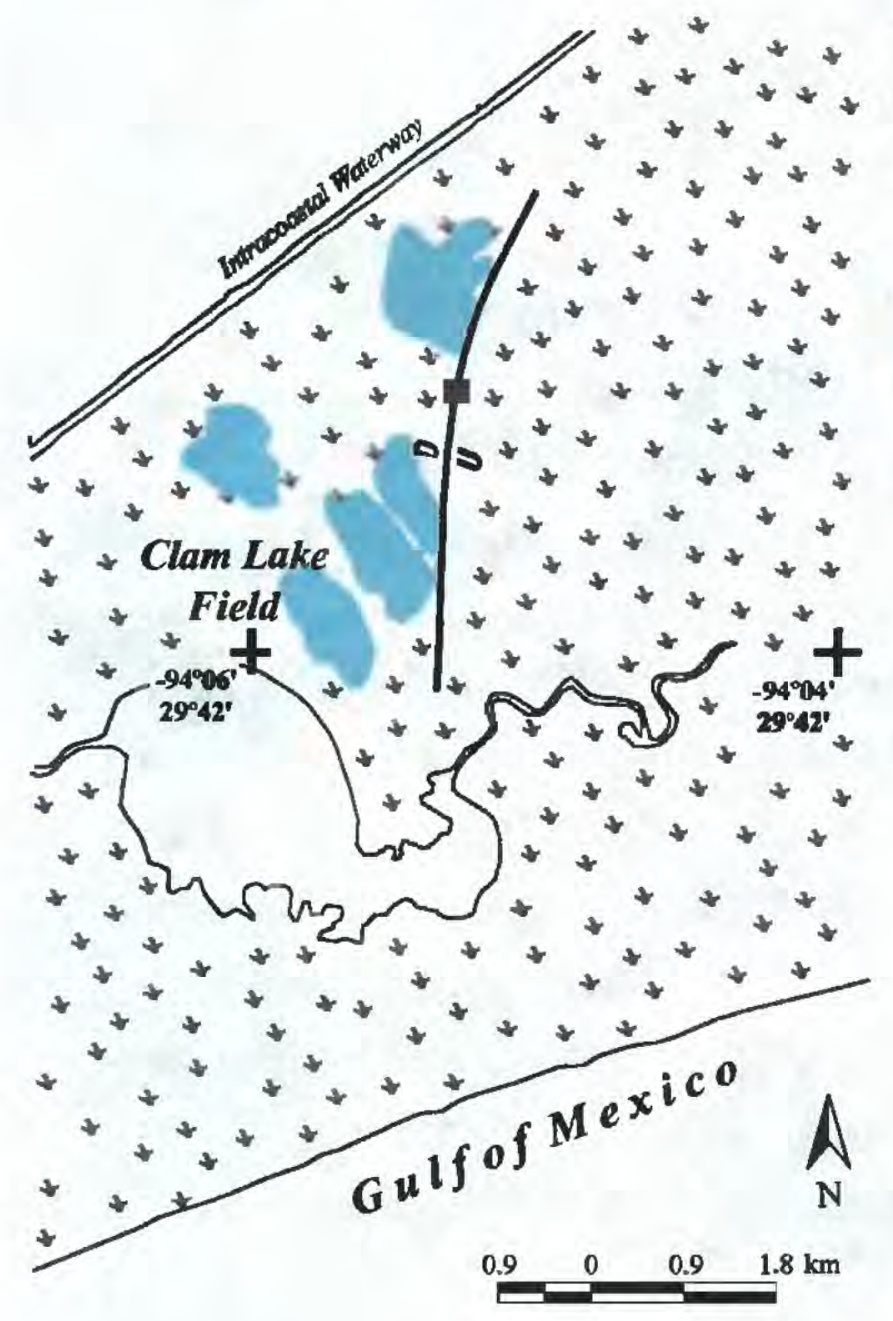

Fig. 3. Location of sediment-surface profile (purple square) surveyed at the Clam Lake Field. Historical wetland loss generalized from White et al. (1987).

Wetland loss between 1956 and 1978. 


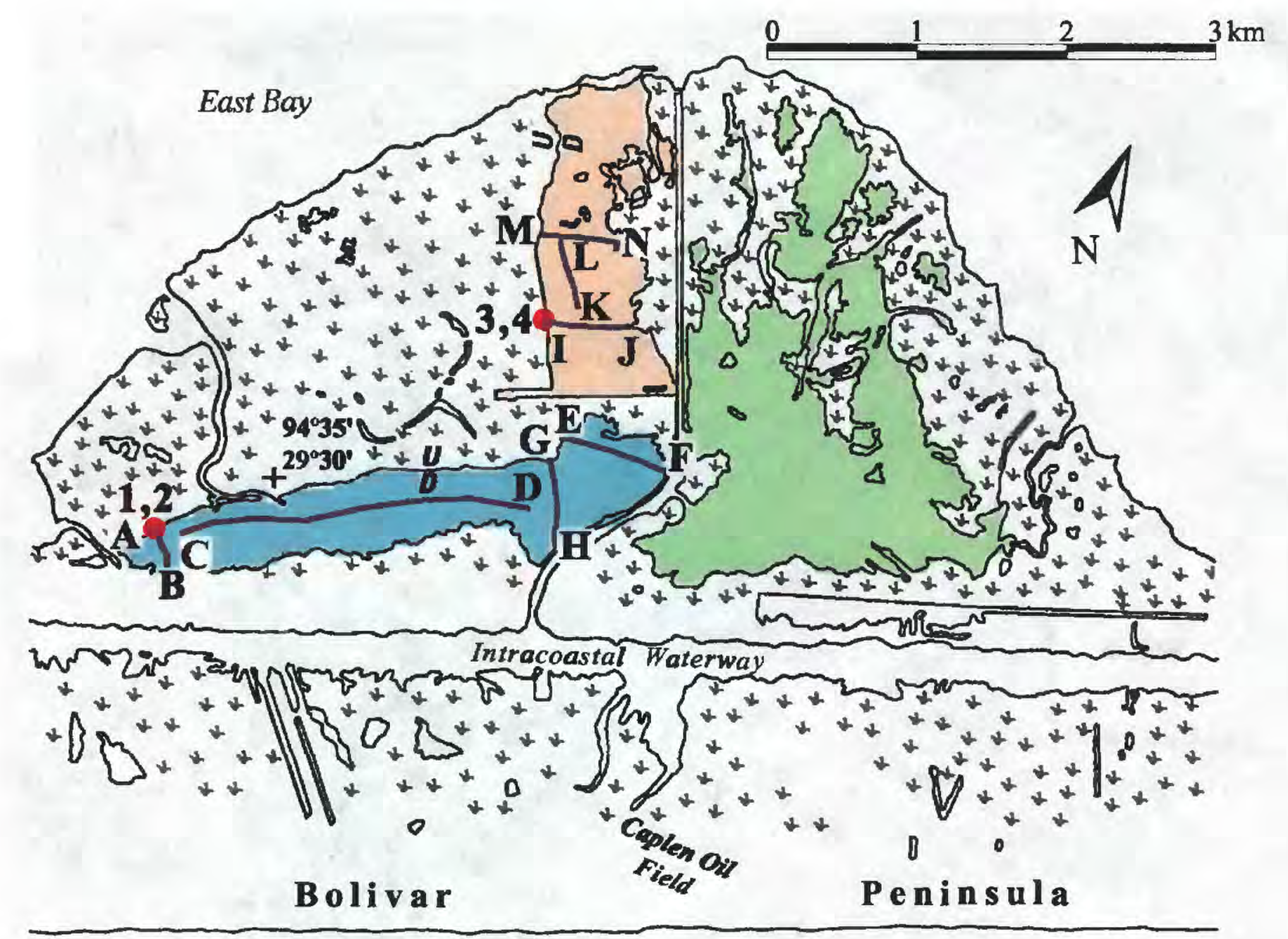

\section{Gulf of Mexico}

Fig. 4. Locations of shallow cores (numbers) and sediment-surface profiles (letters) surveyed at the Caplen Field. Also shown in color are the three areas used to calculate accommodation space created by subsidence and erosion.

\section{Profile Adjustments}

Water depths measured in the field can be compared only if they are corrected for tidal stage or any unusual conditions (such as flooding) that would bias the data. The Conrad Blucher Institute (CBI), Division of Nearshore Research, at Texas A\&M University - Corpus Christi (TAMUCC) operates the Texas Coastal Observation Network (TCOON), which is a network of tide gauges located throughout the coastal waters of Texas. Using electronic tide gauge data from the CBI website, primary water levels for the dates and times of data collection were plotted relative to mean higher high water (MHHW) at the nearest tide gauge (Fig. 1) in the TCOON database. Water levels above or below MHHW during the times of data collection were used to adjust the field measured water depths to a common datum. MHHW was selected as the common datum for comparison because it represents the flooding surface to which wetlands aggrade when they are in equilibrium with the extant coastal processes. Furthermore, the digital waterlevel records provided by $\mathrm{CBI}$ are elevations relative to $\mathrm{MHHW}$, so no additional corrections were necessary for the tidal datum analyses. Water-depth measurements at Port Neches Field 
were adjusted to the MHWW datum from the Rainbow Bridge Station, whereas water-depth measurements at Caplen Field were adjusted to the MHHW datum from the Rollover Pass Station (Fig. 8).

Tide gauge records at the Rainbow Bridge Station, show that average water levels for $06 / 18 / 00$ were $+0.06 \mathrm{~m}$ above MHHW (Fig. 8). Consequently, the water depths measured at Port Neches were adjusted downward by $0.06 \mathrm{~m}$. The tide gauge records at Rollover Pass for $06 / 20 / 00$ and $06 / 21 / 00$ indicate that average water levels were $+0.12 \mathrm{~m}$ and $+0.01 \mathrm{~m}$ above MHHW, respectively, during the field operations (Fig. 8). Therefore, the appropriate values were subtracted from all water depths measured on the respective days. The TCOON water-level data confirm field observations at Caplen that tidal conditions were higher on 06/20/00 than on $06 / 21 / 00$.

\section{Profile Descriptions}

Bathymetric profiles across the Port Neches Field show that water depths of slightly less than $1 \mathrm{~m}$ are relatively uniform except at the marsh edges or where dredged material has been deposited along a channel (Fig. 5). Average water depths are only slightly greater along profile O-P (Appendix A), which runs roughly parallel to a reactivated fault that is downthrown to the northwest (White and Morton, 1997). Together the Port Neches sediment-surface profiles describe a bowl-shaped area of wetland loss with relatively steep sides at the margins and relatively uniform depths within the bowl.

At Clam Lake, the topographic profile was positioned so that it crossed a long reactivated fault segment (Fig. 3). Along the transect, plant density is high, and local variations in elevation
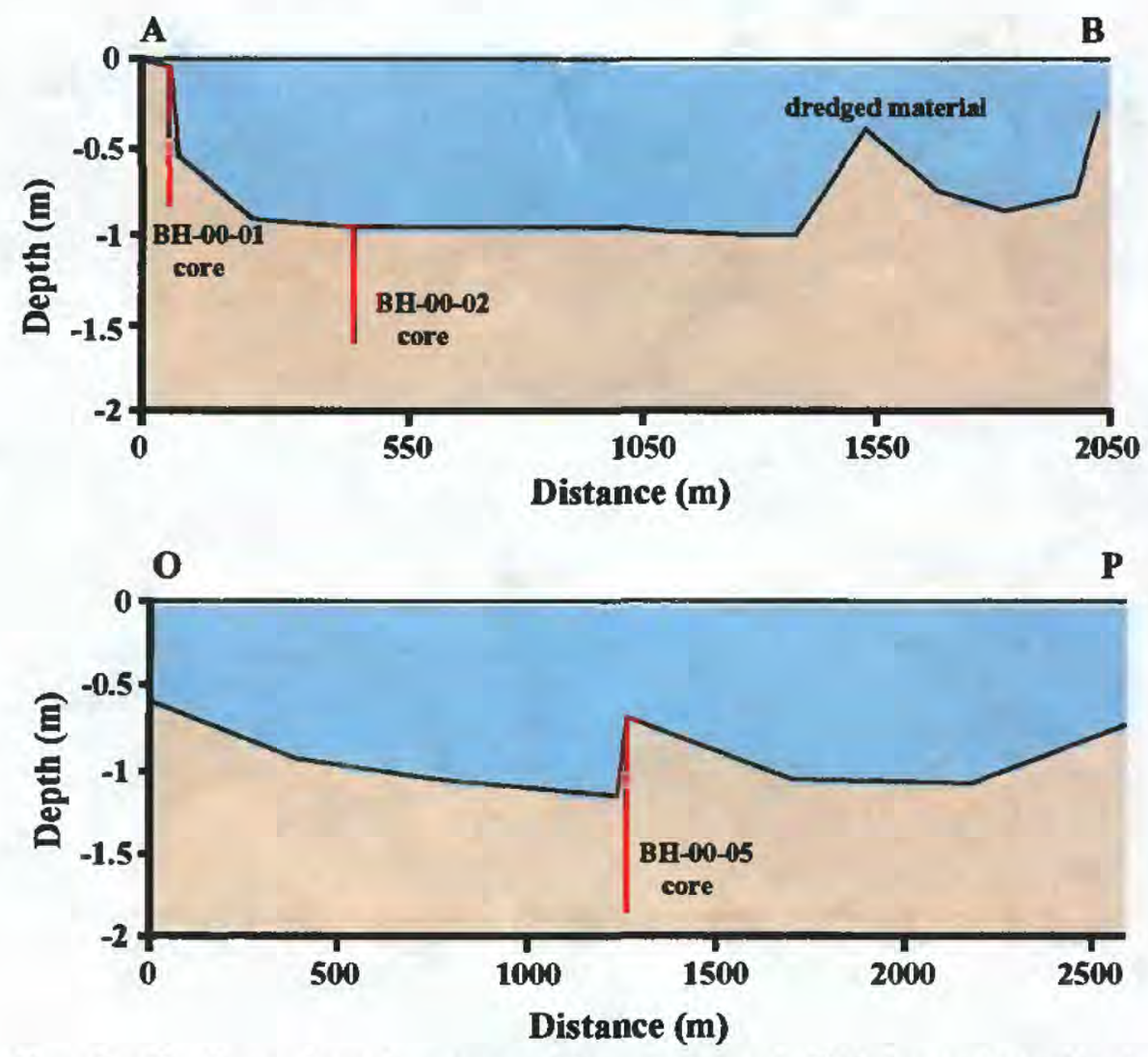

Fig. 5. Sediment-surface profiles $A B$ and $O P$ from the Port Neches Field. Profile locations shown on Fig. 2. 
can be caused by clumps of roots as well as changes in ground level. Because the local groundlevel variability is high, the relative heights of the profile do not show the exact location of the fault (Fig. 6). Instead, the general slope of the profile, average heights of beginning and ending segments, and change in predominant wetland vegetation define the region of the fault. The lateral change in marsh vegetation from Scirpus spp. (bulrush) to Typha spp. (cattail) coincides with slightly lower heights and wetter conditions on the downthrown side of the fault.

The marsh and open-water profiles at the Caplen Field (Fig.7) show that the sedimentsurfaces perpendicular to the fault traces are asymmetrical. Slopes from the marsh to open water are steep across the faults, but slopes are gradual away from the faults (see Appendix A, profiles $\mathrm{AB}, \mathrm{IJ}$, and $\mathrm{MN}$ ). Maximum water depths at Caplen away from the marsh edge or dredged material are typically about $0.6 \mathrm{~m}$. Water bottoms near the faults consist of firm mud, and oyster shells are commonly present.

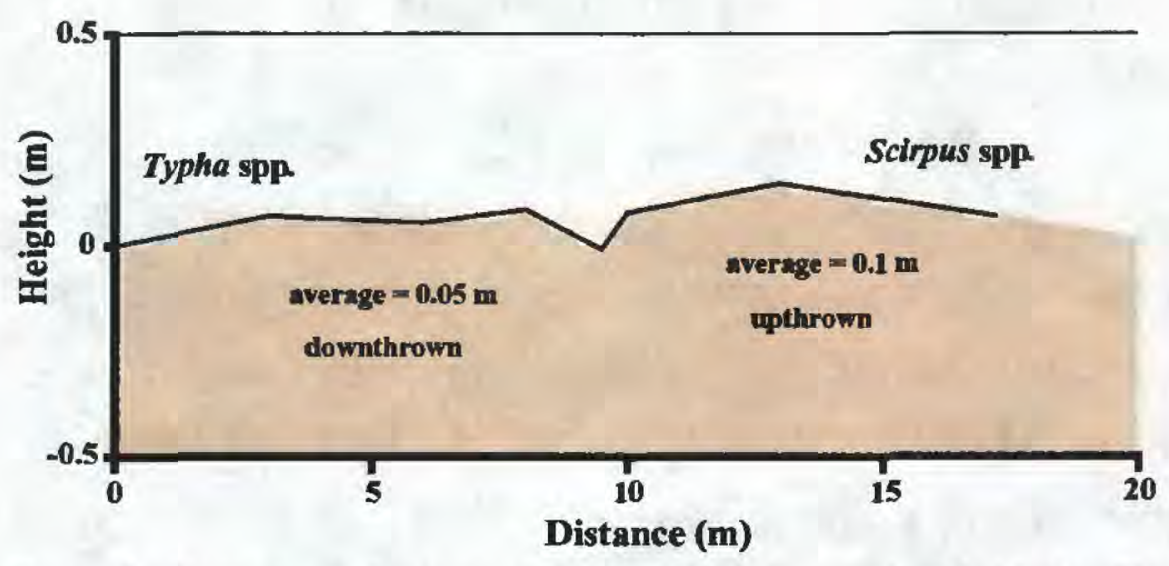

Fig. 6. Sediment-surface profile from the Clam Lake Field. Profile location shown on Fig. 3.
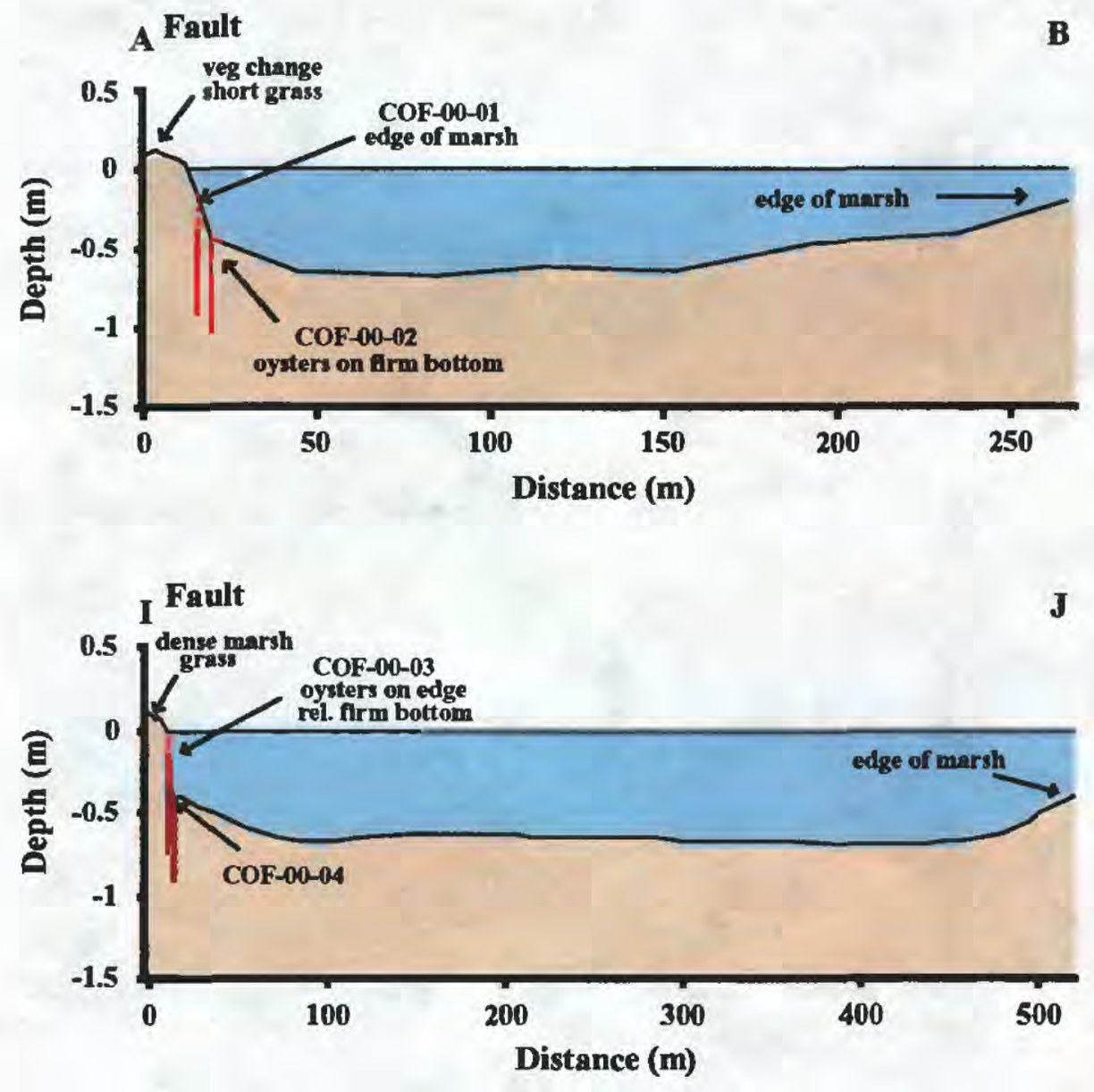

Fig. 7. Sediment-surface profiles $A B$ and IJ from the Caplen Field. Profile locations shown on Fig. 4. 


\section{Estimating Open-Water Accommodation Space}

Individual topographic and bathymetric transects were selected to represent the spatial distribution of marsh and open water in each area of subsidence and fault reactivation. Measurements at all data points visited in the field were included in the topographic and bathymetric profiles; however, an ' $x$ ' on the profile (Appendix $A$ ) identifies a data point that was not included in the calculation of average water depths along the bathymetric profile. Calculations of average water depth and open-water accommodation space do not include these data points because they are either adjacent to or on the natural marsh surface, or on the surface of dredged material. Topographic gradients are relatively steep between the marsh and adjacent open water, and inclusion of water depths at the marsh edge would bias (decrease) the average depths of the open water and underestimate the volume of open-water accommodation space.

To estimate the volume of open-water accommodation space, each field site (Caplen and Port Neches) was divided into three sectors. The area $\left(\mathrm{m}^{2}\right)$ for each sector was determined by drawing polygons around the sectors on a digital quadrangle map (Caplen) and on a digital orthophoto quarter quadrangle (Port Neches). The open-water accommodation space for each sector was calculated by multiplying the surface open-water area $\left(\mathrm{m}^{2}\right)$ and the average water depth $(\mathrm{m})$ for that area. Considering the potential error in water-level adjustments from tide gauge records (a few $\mathrm{cm}$ ) and the potential error in each water-depth measurement $(0.5 \mathrm{~cm})$, it is estimated that the maximum potential error in accommodation space is about $150,000 \mathrm{~m}^{3}$ for the largest open-water sectors ( 1 and 3 ) of the Port Neches Field. Errors in estimating accommodation space in all three sectors at Caplen and in sector 1 at Port Neches are probably substantialy less than the maximum potential error because the areas of these latter sectors are less than half of the largest open-water areas at Port Neches.

Accommodation space associated with wetland loss at the Clam Lake Field was not systematically estimated because no sediment-surface profiles were obtained in the open-water areas. Nevertheless accommodation space there can be approximated by taking the area of open water (275 hectares) measured by White and Tremblay (1995) and inferring that average water depths are about $0.4 \mathrm{~m}$ based on the average water depths measured at Caplen. Those values yield an estimated accommodation space of $1,100,000 \mathrm{~m}^{3}$.

The three sectors of wetland loss at Caplen (Fig. 4) were divided by drawing polygons: 1) along the east-west trending fault trace, 2) along the north-south trending fault trace, and 3) at the eastern side of the dredged canal (Sun Oil Company). The open-water accommodation spaces for sectors 1,2 , and 3 at Caplen are $943,400 \mathrm{~m}^{3}, 729,100 \mathrm{~m}^{3}$, and $1,794,200 \mathrm{~m}^{3}$, respectively. The total volume of accommodation space in the Caplen Field is about $3,466,700 \mathrm{~m}^{3}$.

Transect locations and road segments that are still exposed controlled the division of Port Neches into three areas of wetland loss. The open-water accommodation spaces estimated for sectors 1, 2, and 3 at Port Neches are $6,623,400 \mathrm{~m}^{3}, 2,492,600 \mathrm{~m}^{3}$, and $6,210,800 \mathrm{~m}^{3}$, respectively. The total volume of accommodation space in the Port Neches Field is approximately $15,326,800 \mathrm{~m}^{3}$. 

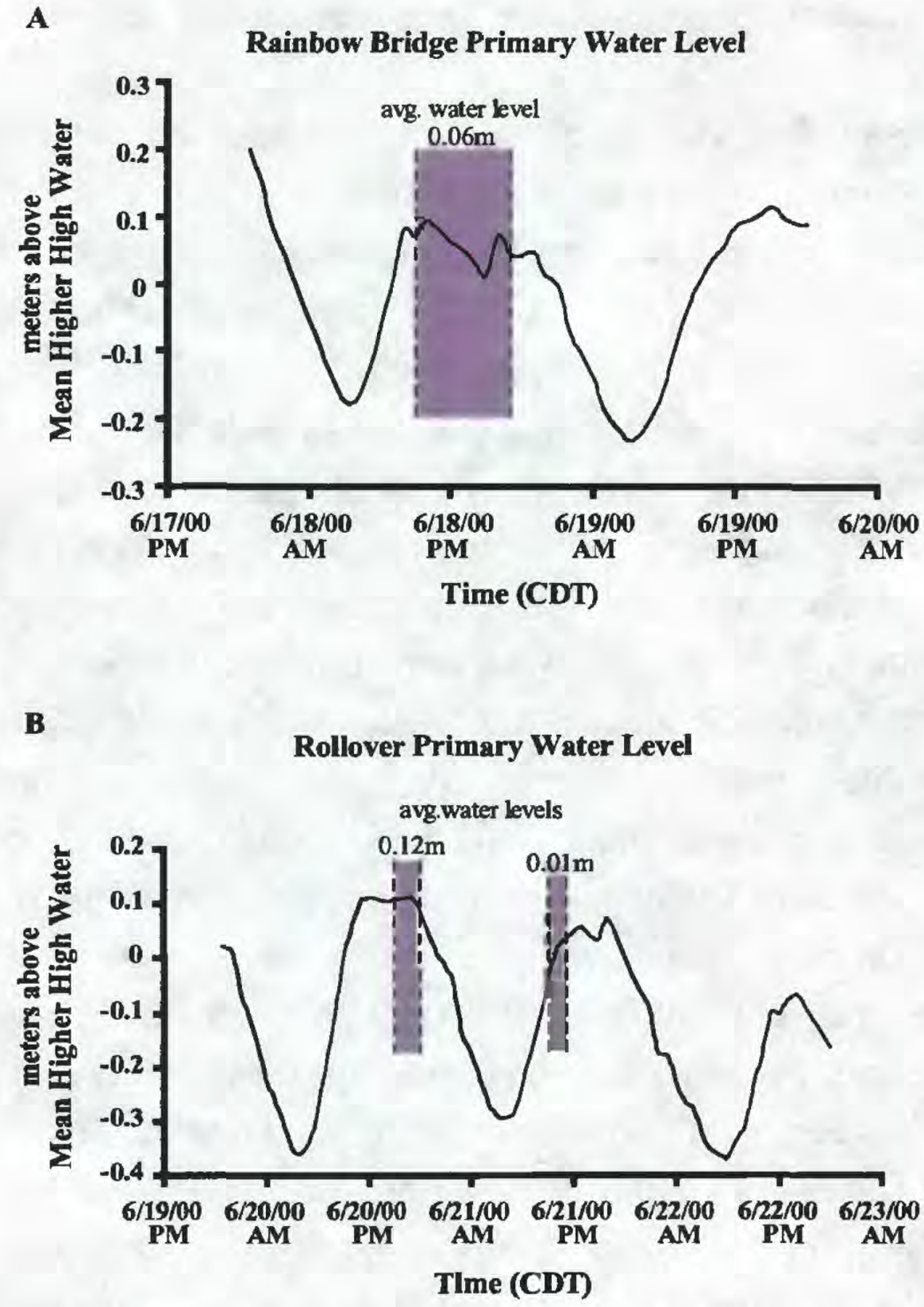

Fig. 8. Water levels recorded at the (A) Rainbow Bridge and (B) Rollover Pass tide gauges during the field investigation. Locations of tide gauges shown on Fig. 1.

\section{SEDIMENT CORES}

Ten short sediment cores (Appendix B) were obtained from the Port Neches (6) and Caplen (4) field sites (Figs. 2 and 4). The cores, which range in length from 0.5 to $1.15 \mathrm{~m}$, were transported to the USGS Center for Coastal and Regional Marine Studies at St. Petersburg, Florida. There each core was split, photographed, described, and archived. Cores from the Port Neches Field were collected in open water near the marsh edge to evaluate the magnitudes of subsidence or erosion. An exception is core BH-00-01, which was taken at the marsh edge to establish the natural thickness of marsh sediments. At the Caplen Field, two pairs of cores were taken from the marsh and adjacent open water perpendicular to surface fault traces. The sites were selected to sample the upthrown and downthrown sides of the east-west and northsouth trending faults (Fig. 4). All of the cores coincide with one of the topographic profiles (Appendix A). 


\section{Core Descriptions and Sediment Types}

The six cores from Port Neches define three different stratigraphic successions. Cores BH-00-01, 02, and 06 exhibit essentially the same stratigraphy that consists of three sedimentary facies (Fig. 9). Those general facies, from top to bottom, are black or dark gray organic mud with abundant roots, dark gray mud, and light gray or olive-gray mud. The light gray mud is mottled to faintly laminated. Cores BH-00-03 and 05 are the deepest cores and yet they recovered only two general sedimentary facies; olive black organic mud and thinly bedded or laminated dark and light gray mud. The dark and light laminations consist of both different colors and compositions that reflect organic content and the balance between fine-grained clastic and organic sedimentation within the floodplain of the Neches River. Core BH-00-04 also encountered three sedimentary facies; black to dark gray mud and sandy mud, brownish black organic mud, and light olive brown mud and muddy sand. The dark mud and sandy mud that comprises the top 6 $\mathrm{cm}$ represents recent subaqueous deposition that post-dates erosion of the adjacent marsh surface. The underlying dark organic mud represents late Holocene wetland deposits, whereas the deeper light brown mud and muddy sand are interpreted as late Pleistocene fluvial deposits of the Deweyville Formation (Morton et al., 1996). These same Pleistocene terrace deposits form the forested surface with accretionary ridges just south of the coring site.

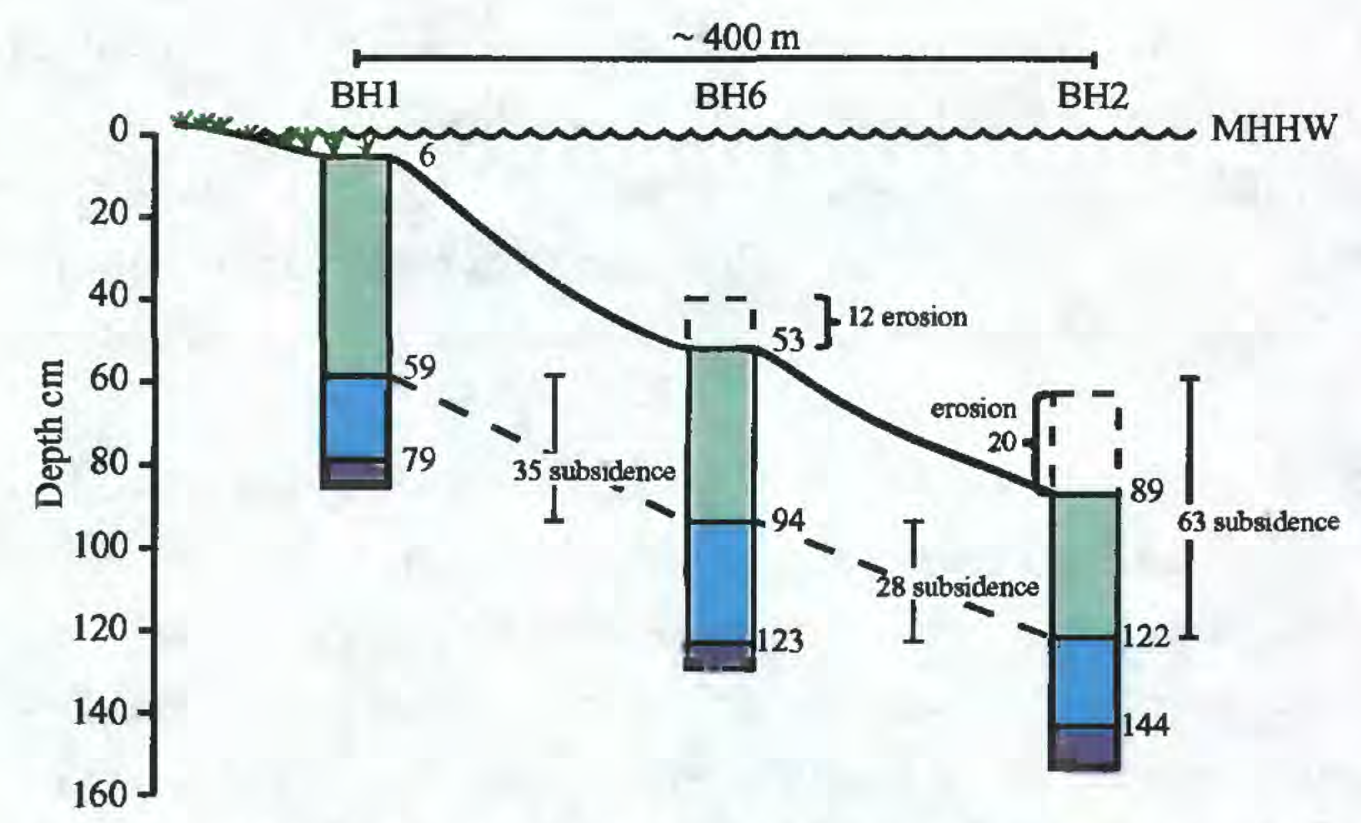

Fig. 9. Stratigraphic correlations of cores illustrate the magnitude of wetland subsidence around the Port Neches Field. Sedimentary facies in the cores, from top to bottom, are organic mud, dark gray mud, and light gray mud.

The four cores from the Caplen Field recovered some or all of the same three sedimentary facies observed in the Port Neches cores, two of the cores recovered an additional facies, which is sandy mud. The general facies colors and compositions in stratigraphic order from top to bottom are: (1) black organic mud with abundant roots, and dark gray and light gray mud with some roots, (2) light gray or light brown sandy mud, and (3) mud and sand in horizontal juxtaposition. 
The light-colored mud and sand-mud facies are mottled to faintly laminated. Cores COF-00-03 and 04 recovered all three facies, whereas cores COF-0001 and 02 recovered primarily the upper two facies. The complete upward-fining stratigraphic section records upward shoaling and establishment of a marsh with increased organic-sediment production and decreased clastic sedimentation.

Comparing the shallow wetland stratigraphy at Port Neches and Caplen reveals that the organic-rich sediments are substantially thicker at Port Neches $(>30 \mathrm{~cm})$ than at Caplen (< $20 \mathrm{~cm}$ ) probably because of the aggradational floodplain setting at Port Neches. The clastic sediments contain more sand at Caplen because of a barrier-island setting.

\section{Stratigraphic Correlations and Subsidence-Erosion Calculations}

The following methods were used to estimate the magnitude of subsidence or erosion by comparing the stratigraphy of adjacent cores. Core pairs were placed on a laboratory bench and juxtaposed so that the marker horizons or sedimentary facies correlated. The correlated horizons were marked with labels, and the depths from the top of the core to each marker horizon were recorded. Cores were then placed in their proper vertical positions relative to surface elevations and water depths in the field. The depth differences of the labeled markers were measured, and an estimate of subsidence was calculated as well as the indicated depth of erosion. Stratigraphic correlations were established among all cores except BH-00-04, which came from a different geologic setting where the transition from floodbasin muds to marsh sediments is not present. The subsidence and erosion estimates depended on the assumptions that: (1) the thickness of marsh sediments at BH-00-01 $(53 \mathrm{~cm})$ is a reasonable estimate of original marsh sediment thickness at each core location, and (2) there has been no subsidence or erosion at $\mathrm{BH}-00-01$. If the original marsh thickness at a site was less than $53 \mathrm{~cm}$, then the methods underestimate subsidence and overestimate erosion.

Most of the cores at Port Neches were taken along the marsh edge bordering open water (Fig. 2) to compare the thickness of extant marsh sediments at the surface with the thickness of organic-rich mud (marsh sediments) preserved beneath the water. One core (BH-00-02) was taken approximately $400 \mathrm{~m}$ toward the center of the bowl-shaped area of wetland loss to sample the thickness of organic-rich mud away from the marsh edge that might be influenced by wave and current erosion. Three cores collected from the western side of Port Neches (BH-00-01, $\mathrm{BH}-00-02$, and $\mathrm{BH}-00-06$ ) were correlated to determine the amount of subsidence or erosion that has taken place from the marsh edge toward the center of the open-water area. All three cores exhibit three distinct vertical sedimentary facies changes that can be correlated (Fig. 9). Between BH-00-01 (core of marsh surface) and BH-00-06 (core near marsh edge) there were approximately $35 \mathrm{~cm}$ of subsidence and $12 \mathrm{~cm}$ of marsh erosion. Between cores BH-00-06 and BH-00-02 (farthest from marsh edge) approximately $28 \mathrm{~cm}$ of subsidence and $8 \mathrm{~cm}$ of erosion were measured (Fig. 9). Comparing cores BH-00-01 and BH-00-02, $63 \mathrm{~cm}$ of subsidence and $20 \mathrm{~cm}$ of erosion were measured. At core site BH-00-05 (Fig. 2), about $36 \mathrm{~cm}$ of subsidence 
and $21 \mathrm{~cm}$ of erosion are estimated from the thickness of organic mud with abundant roots at the top of the core $(32 \mathrm{~cm})$ and the adjusted water depth $(63 \mathrm{~cm})$ at the site. The thickness $(0.59 \mathrm{~m})$ of organic-rich sediments at the top of core BH-00-03 suggests that none of the marsh sediments has been eroded from that site and the adjusted water depth $(0.87 \mathrm{~m})$ is a reasonable estimate of subsidence.

Caplen core pairs COF-00-01 and COF-00-02, and COF-00-03 and COF-00-04 were correlated to determine the amount of subsidence or erosion. Land-surface changes at the Caplen Field were determined by correlating marker horizons in two pairs of cores taken on the upthrown and downthrown sides of the reactivated faults (Fig. 10). Stratigraphic correlations between COF-00-01 (upthrown) and COF-00-02 (downthrown) indicate a downthrown offset (subsidence) of only $0.04 \mathrm{~m}$ across the east-west trending fault, whereas approximately $0.31 \mathrm{~m}$ of the top of core COF-00-2 is absent as a result of erosion. The organic-rich zone representing the marsh surface is missing from COF-00-02 (Fig. 10). Three distinct vertical facies changes can be correlated in the pair of Caplen cores (COF-00-03 and COF-00-04) taken across the north-south trending fault (Fig. 10). Correlation of the upper two stratigraphic horizons indicate $0.04 \mathrm{~m}$ of subsidence, whereas vertical displacement of the lower stratigraphic horizon indicates $0.19 \mathrm{~m}$ of subsidence. The lower section of core $\mathrm{COF}-00-03$ may have experienced core shortening (Morton and White, 1997), which would explain the difference in measured subsidence at the upper and lower horizons. The stratigraphic correlations also indicate that core COF-00-04 was taken at a location where approximately $0.39 \mathrm{~m}$ of the organic-rich marsh and underlying sediments have been removed by erosion.
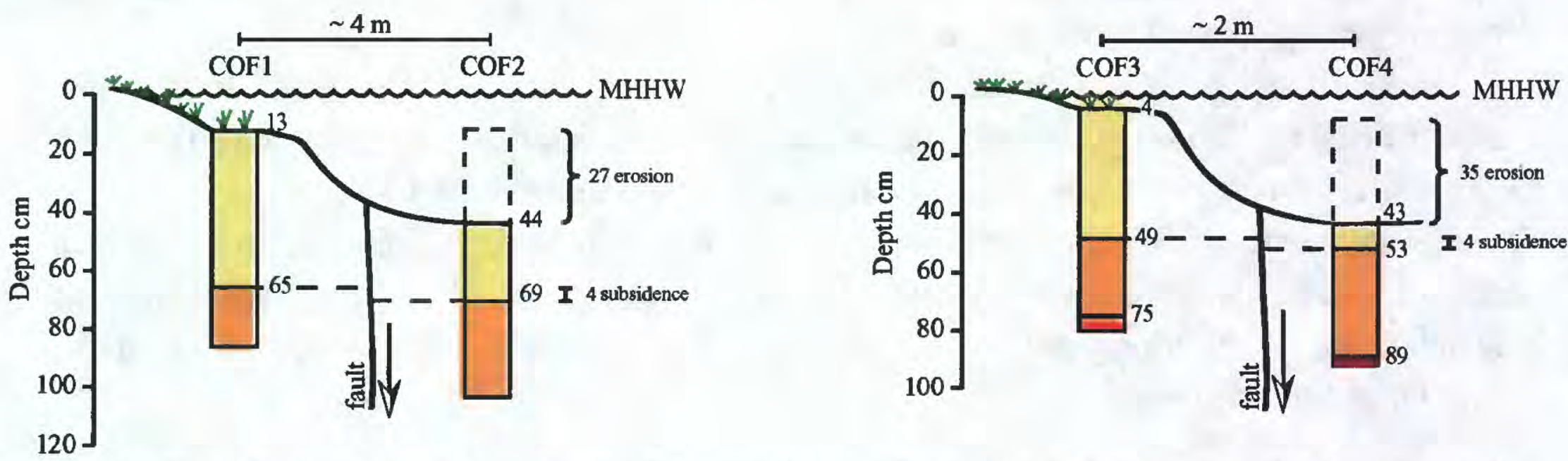

Fig. 10. Stratigraphic correlations of core pairs illustrate the magnitude of fault-controlled wetland erosion at the Caplen Field. Sedimentary facies in the cores, from top to bottom, are organic mud, sandy mud, and heterogeneous sand and mud.

\section{Historical and Geological Subsidence Rates}

A subsidence rate can be approximated for the Port Neches Field by integrating the spatial data presented in Fig. 5 (line AB) and the temporal data presented in White and Morton (1997). According to that information, the wetland surface at Port Neches subsided about $64 \mathrm{~cm}$ between 
1956 and 1978 ( $22 \mathrm{yrs})$. These values yield a short-term average rate of wetland subsidence of nearly $3 \mathrm{~cm} / \mathrm{yr}$. The estimated subsidence rate may be conservative because the maximum period was used to calculate the rate. Although the observed subsidence occurred after 1956 and before 1978 , it is unclear when the maximum vertical displacement occurred. The similarity in areal wetland loss in 1978 compared with present (2000) conditions suggests that the subsidence was rapid initially, but then slowed or possibly stopped. It is not likely that subsidence would be sustained indefinitely. Instead, the duration of surficial adjustment to subsurface perturbations is probably related to the history of production. There was a hiatus between the onset of production and the first visible evidence of surface disturbance and wetland loss. Whatever losses are occurring today, they are occurring at a much slower rate than when the wetlands collapsed between 1956 and 1978. This temporal reduction in rates of subsidence corresponds with the rapid decline in hydrocarbon production.

The estimated rate of production-induced subsidence at Port Neches $(3 \mathrm{~cm} / \mathrm{yr})$ is rapid compared to natural rates of subsidence in the Gulf Coast region over geological time scales. For example, geological rates of subsidence are known to be relatively rapid in parts of the Mississippi delta. Some of the highest long-term average rates of subsidence in south Louisiana are on the order of $1 \mathrm{~cm} / \mathrm{yr}$ (Roberts et al., 1994; Kulp and Howell, 1998). However, most of the peats more than 200 years old yielded subsidence rates less than $0.5 \mathrm{~cm} / \mathrm{yr}$. The highest geological rates of subsidence were located where the Holocene delta deposits are thickest. The young, water-saturated peats and muddy delta sediments have the greatest potential for rapid subsidence as the sediments naturally dewater and compact. Farther to the west, away from the incised valley where Holocene sediments are thickest, calculated rates of natural subsidence are on the order of $0.04 \mathrm{~cm} / \mathrm{yr}$ (Roberts et al., 1994).

The short-term historical rates of subsidence at Port Neches $(3 \mathrm{~cm} / \mathrm{yr})$ are essentially three times the highest long-term average rates of subsidence in a region that is known for rapid subsidence. Considering the geological setting at Port Neches with the underlying overcompacted Pleistocene sediments, the $3 \mathrm{~cm} / \mathrm{yr}$ rate is relatively high compared to expected natural rates of subsidence. The historical subsidence rates at Port Neches are 75 times the geological rates in the delta plain of southwestern Louisiana, which is the closest area with subsidence data having a similar geologic setting.

\section{DISCUSSION OF RESULTS}

\section{Subsidence versus Marsh Erosion}

At Port Neches, the uppermost stratigraphic unit of each core contains at least $0.32 \mathrm{~m}$ of organic-rich sediments. These organic-rich sediments are the same unconsolidated and rooted muds that comprise the present marsh facies recovered in BH-00-01. Considering the thickness of organic-rich sediments in the cores, less than $20 \mathrm{~cm}$ of marsh sediment has been eroded from the surface over the Port Neches Field. The evidence strongly indicates that the open water 


\section{COASTAL ENVIRONMENTAL IMPLICATIONS}

The different surficial wetland responses and accommodation spaces created by prolonged large-volume hydrocarbon production at each field investigated is partly related to the primary fluid type produced and the rates of production. For example, the greatest wetland loss and creation of accommodation space occurred at the Port Neches Field where the largest measured vertical subsidence was associated with the largest cumulative volume of gas produced. The second greatest wetland loss and creation of accommodation space occurred by minor subsidence and major erosion at the Caplen Field. Significant volumes of both oil and gas were produced at Caplen and the wetland loss was controlled primarily by fault reactivation and subsequent wetland erosion. Wetland losses and creation of accommodation space were the least at the Clam Lake Field, which primarily produced oil with some gas. In fact, the cumulative volume of gas produced at Clam Lake was the least of the three fields studied (Table 1). The wetland losses occurring at Clam Lake are also fault controlled as at Caplen. At both fields it appears that the vertical displacement (subsidence) is less than the breakup of wetlands and conversion to open water by erosion and exportation of organic-rich sediments. Wetland losses are localized around the hydrocarbon fields examined in southeast Texas because the fields are widely spaced relative to the nearest large field. In parts of coastal Louisiana, large fields are relatively close to one another, and there is greater potential for subsidence, faulting, and wetland losses between the fields induced by cumulative production and regional depressurization.

There has been substantial speculation regarding the significance of subsidence in the Gulf Coast region induced by prolonged extraction of hydrocarbons. One-dimensional modeling of reservoir compaction around oil and gas fields in Louisiana suggested that potential land subsidence would be insignificant (Martin and Serdengecti, 1984; Suhayda, 1987). Without debating the accuracy of those conclusions, it is clear that the modeling results focused on the vertical displacement that might be expected and not the impact of that vertical displacement. Subsidence of a meter or less induced by oil and gas production is not great, especially when compared to the extreme examples of subsidence such as $9 \mathrm{~m}$ at Wilmington, California (Yerkes and Castle, 1976) or $4.5 \mathrm{~m}$ at the Ekofisk Field in the North Sea (Mes, 1990). Nevertheless, the relatively small observed reductions in elevation in the Gulf Coast region are sufficient to cause dramatic impacts on the affected wetland ecosystems. This study has demonstrated that even minor lowering of the marsh surface can translate to large wetland losses through a combination of coastal-plain submergence and marsh-sediment erosion.

\section{ACKNOWLEDGMENTS}

We would like to thank B. J. Reynolds for conducting the field surveys, Lauren Shapiro for assistance with the production data, and Betsy Boynton for assistance with the report layout and illustrations. Barbara Lidz and Peter Swarzenski provided editorial and scientific reviews. 
created as a result of wetland loss was caused largely by land-surface subsidence. Subsidence estimates on the west side of Port Neches are based on stratigraphic comparisons with BH-00-01. If the land surface at this location has experienced historical subsidence, but the marsh surface subsequently aggraded, then the estimated magnitudes of subsidence would need to be increased the same amount as the subsidence at BH-00-01. The maximum induced subsidence observed at the Port Neches Field $(0.9 \mathrm{~m}$ at BH-00-03) is the same magnitude of subsidence reported by Ratzlaff (1982) for the nearby Port Acres Field on the basis of releveling surveys.

Slightly greater water depths at Caplen Field along the marsh banks that coincide with the fault traces suggest that scour by currents is enhanced by the boundary conditions.

\section{Geologic Setting}

Each of the three fields is located in a different geologic setting. The Port Neches Field is within the floodplain of an alluvial valley, the Clam Lake Field is within the coastal-plain marsh between major rivers (interfluvial setting) and the Caplen Field is located in a barrier-island setting. However, the different geologic settings do not appear to have any significant influence on the subsidence and fault reactivation responses of the wetlands. Perhaps this is because the Holocene sediments at each site are relatively thin $(<6 \mathrm{~m}$, Morton et al., 1999) and the underlying Pleistocene strata are over-consolidated for their depths because they were subaerially exposed when sea level was lower about $20 \mathrm{ka}$.

\section{Production Characteristics}

Each of the fields experiencing subsidence and fault reactivation has produced for more than 60 years from more than 50 wells that together yielded more than 20 million bbls of oil and $10 \mathrm{Bcf}$ of gas (Table 1). Of the three fields investigated, the greatest subsidence occurred where gas was the primary produced fluid and the rates of production from a relatively small area were exceptionally high, albeit for a brief period. The accelerated gas production causes rapid declines in pore pressure because the withdrawal of fluid greatly exceeds the transmissivity of the formation and its ability to recharge through inflow of water from the aquifer(s) contiguous with or associated with the reservoirs.

Preliminary pressure-depth plots for the Port Neches and Caplen Fields also demonstrate that hydrocarbon production eventually reduces pore pressures to the extent that the increased effective stresses around the reservoirs cause reservoir compaction, subsidence, and fault reactivation. 


\section{REFERENCES}

Chilingarian, G.V., Donaldson, E.C., and Yen, T.F., 1995, Subsidence due to fluid withdrawal: Developments in Petroleum Science 41, Elsevier Science, Amsterdam, 520 p.

Ewing, T.E., 1985, Subsidence and surface faulting in the Houston-Galveston area, Texas related to deep fluid withdrawal. In, Dorfman, M.H., and Morton, R.A. (eds.), Geopressured Geothermal Energy: Proceedings of the $6^{\text {th }}$ U.S. Gulf Coast Geopressured-Geothermal Conference, Pergamon Press, New York, p. 289-298.

Holzer, T. L., and Bluntzer, R. L., 1984, Land subsidence near oil and gas fields, Houston, Texas: Ground Water, v. 22, p. 450-459.

Kiatta, H.W., 1986, Port Neches North (Hackberry) Orange County, Texas. In Typical Oil and Gas Fields of Southeast Texas II: Houston Geological Society, p. 390-395.

Kreitler, C.W., 1978, Fauliting and land subsidence from ground-water and hydrocarbon production: The Univ. of Texas at Austin, Bureau of Economic Geology, Research Note 8, 22p.

Kreitler, C.W., Akhter, M.S., Donnelly, A.C.A., and Wood, W.T., 1988, Hydrogeology of formations used for deep-well injection, Texas Gulf Coast: Univ. Texas at Austin Bureau of Economic Geology, prepared for EPA, Cooperative Agreement No. CR812786-01-0, 204p.

Kulp, M A; Howell, P D, 1998, Assessing the accuracy of Holocene subsidence rates in southern Louisiana as indicated by radiocarbon-dated peats: Abstracts with Programs - Geological Society of America, v. 30, no.7, p. 142.

Martin, J.C., and Serdengecti, S., 1984, Subsidence over oil and gas fields, In Holzer, T.L., Reviews in Engineering Geology, v. VI, p. 23-34.

Mes, M.J., 1990, Ekofisk reservoir pressure drops and seabed subsidence: $22^{\text {nd }}$ Annual Offshore Technology Conference, v. 1, p. 373-387.

Morton, R. A., Blum, M. D., and White, W. A., 1996, Characteristics of incised valley fills, coastal plain rivers of southeastern Texas: Transactions Gulf Coast Association of Geological Societies, v. 46, p. 321-331.

Morton, R. A., Kindinger, J. L., Flocks, J. G., and Stewart, L. B., 1999, Climatic and eustatic control of Holocene nearshore parasequence development, southeastern Texas coast: Transactions Gulf Coast Association of Geological Societies, v. 49, p. 384-395.

Morton, R. A., and White, W. A., 1997, Characteristics of and corrections for core shortening in unconsolidated sediments: Journal of Coastal Research, v. 13, p. 761-769.

Musolff, N.C., 1962, Caplen Field, Galveston County, Texas, In Denham, R.L., ed., Typical Oil and Gas Fields of Southeast Texas I: Houston Geological Society, p. 30-33. 
Naidoo, G., McKee, K.L., and Mendelssohn, I.A., 1992, Anatomical and metabolic responses to waterlogging and salinity in Spartina alterniflora and S. patens (Poaceae): American Journal of Botany, v. 79, p. 765-770.

Pratt, W. E., and Johnson, D. W., 1926, Local subsidence of the Goose Creek oil field: Journal of Geology, v. 34, p. 577-590.

Ratzlaff, K.W., 1982, Land-surface subsidence in the Texas coastal region: Texas Department of Water Resources Report 272, 26 p.

Roberts, H.H., Bailey, A., and Kuecher, G.J., 1994, Subsidence in the Mississippi River delta Important influences of valley filling by cyclic deposition, primary consolidation phenomena, and early diagenesis: Transactions Gulf Coast Association of Geological Societies, v. 44, p. 619-629.

Sharp, J.M., Jr., and Hill, D.W., 1995, Land subsidence along the northeastern Texas Gulf Coast: Effects of deep hydrocarbon production: Environmental Geology, v. 25, p. 181-191.

Suhayda, J.N., 1987, Subsidence and sea level, In Turner, R.E. and Cahoon, D.R., eds., Causes of Wetland Loss in the Coastal Central Gulf of Mexico, v. II Technical Narrative, Minerals Management Service OCS Study MMS87-0120, p. 187-202.

White, W. A., Calnan, T. R., Morton, R. A., Kimble, R. S., Littleton, T. G., McGowen, J. H., Nance, H. S., and Schmedes, K. E., 1987, Submerged lands of Texas, Beaumont-Port Arthur area: sediments, geochemistry, benthic macroinvertebrates, and associated wetlands: The Univ. of Texas at Austin, Bureau of Economic Geology, 110p.

White, W. A., and Morton, R. A., 1997, Wetland losses related to fault movement and hydrocarbon production, southeastern Texas coast: Journal of Coastal Research, v. 13, p. 1305-1320.

White, W.A., and Tremblay, T.A., 1995, Submergence of wetlands as a result of human-induced subsidence and faulting along the upper Texas Gulf Coast: Journal of Coastal Research, v. 11, p. 788-807.

Williams, K.O., 1962, Clam Lake Field, Jefferson County, Texas, In Denham, R.L., ed., Typical Oil and Gas Fields of Southeast Texas I: Houston Geological Society, p. 34-37.

Wiprut, D., and Zoback, M., 2000, Fault reactivation and fluid flow along a previously dormant normal fault in the northern North Sea: Geology, v. 28, p. 595-598.

Yerkes, R.F., and Castle, R.O., 1976, Seismicity and faulting attributable to fluid extraction: Engineering Geology, v. 11, p. 151-167. 


\section{APPENDIX A: TOPOGRAPHIC PROFILES}




\section{Clam Lake Topographic Profile}

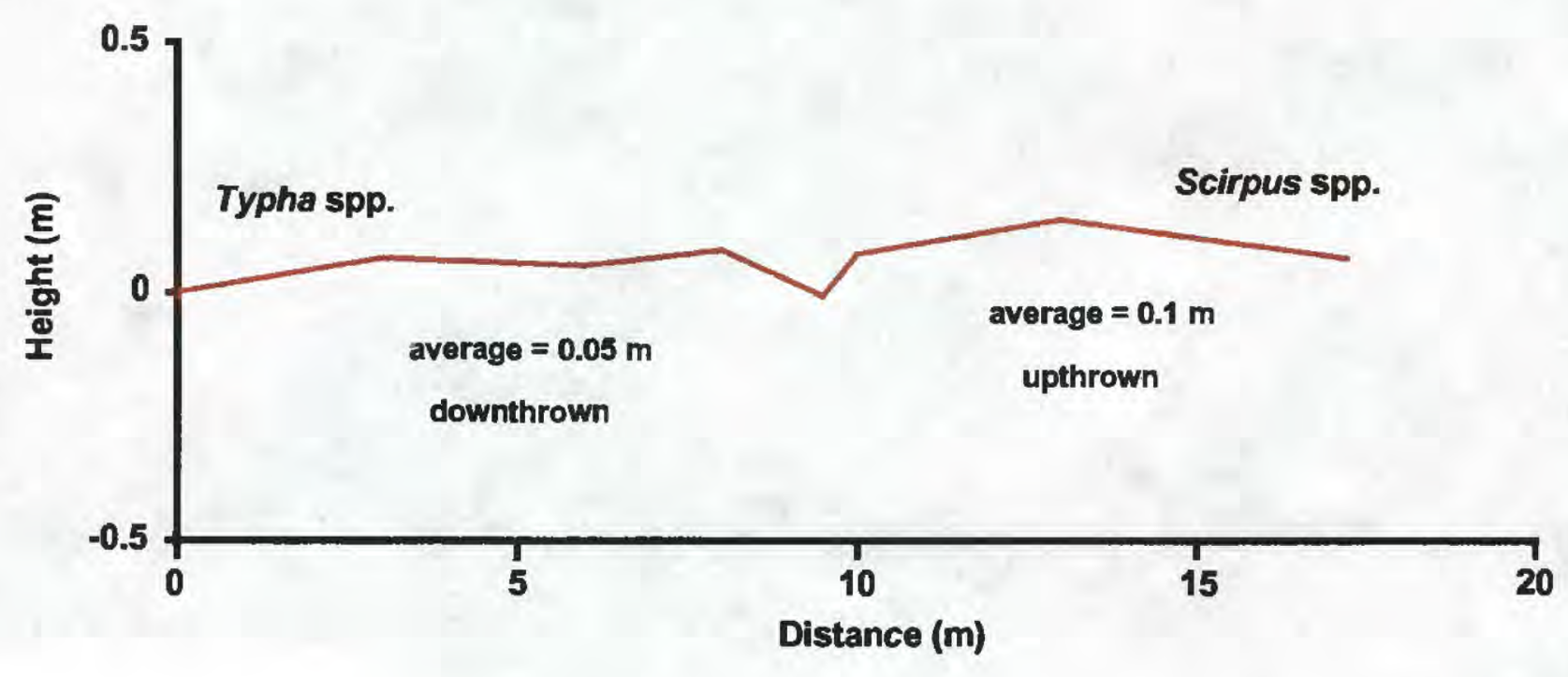




\section{Port Neches Bathymetric Profiles}
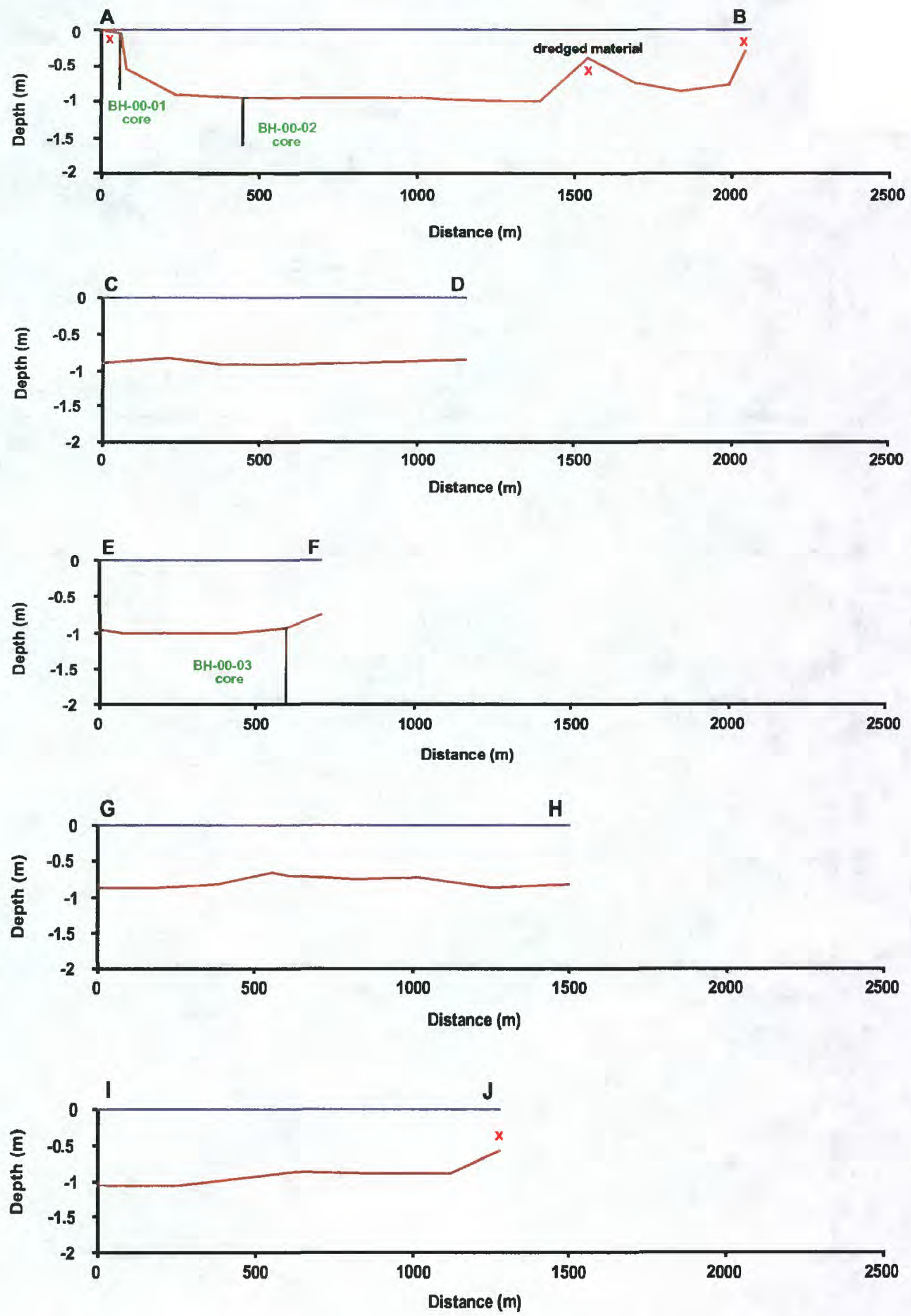
Port Neches Bathymetric Profiles (continued)
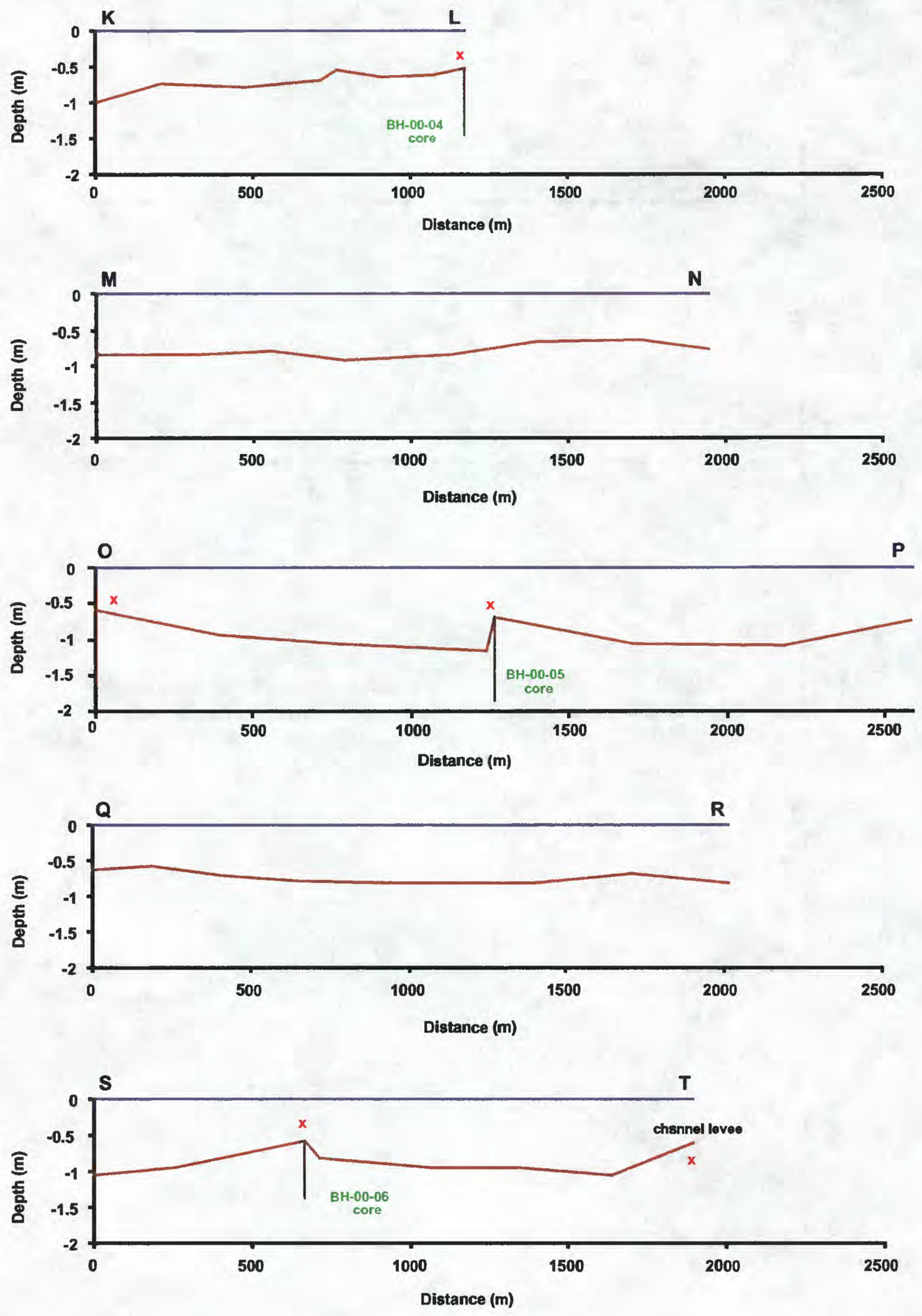


\section{Caplen Bathymetric Profiles}
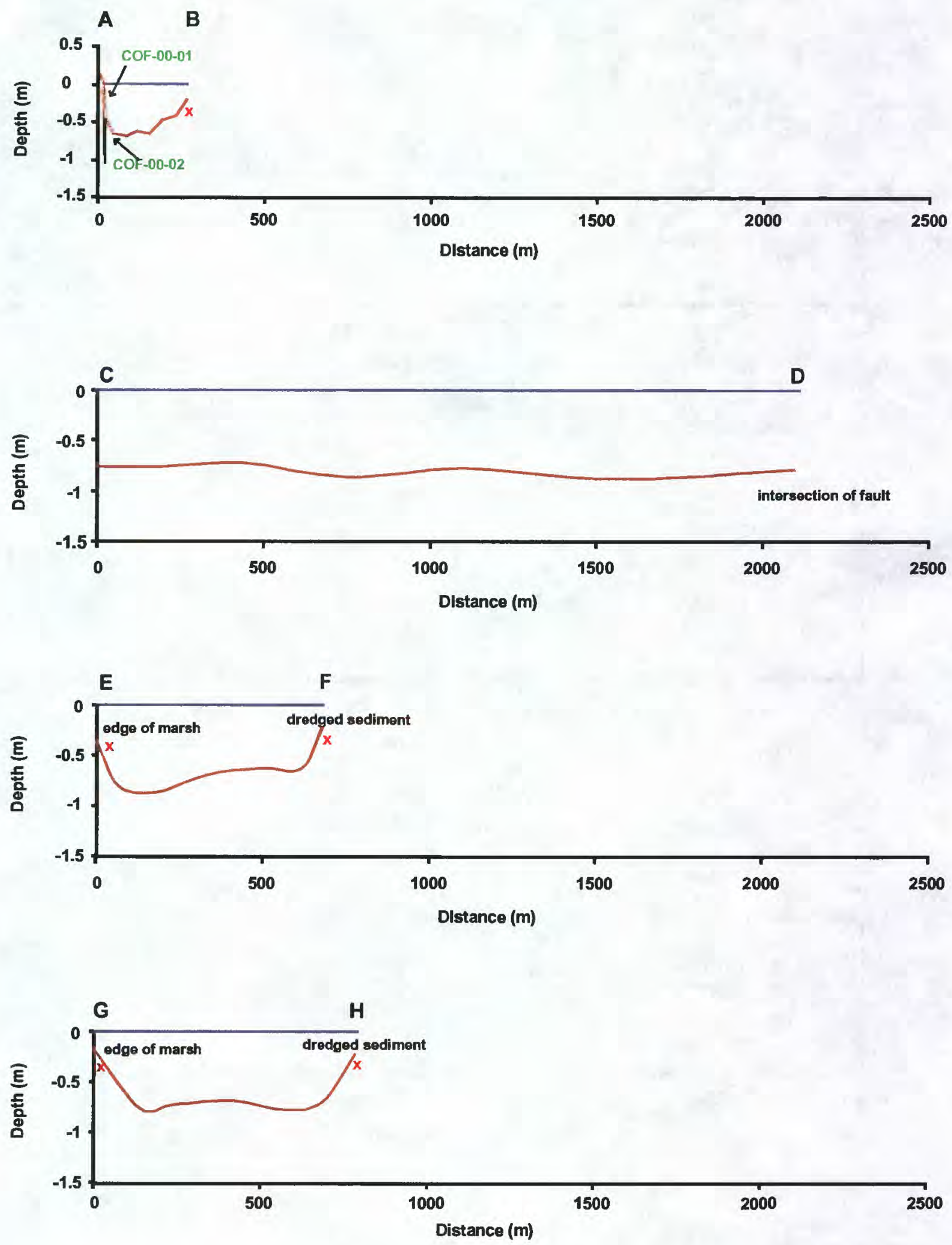


\section{Caplen Bathymetric Profiles (continued)}
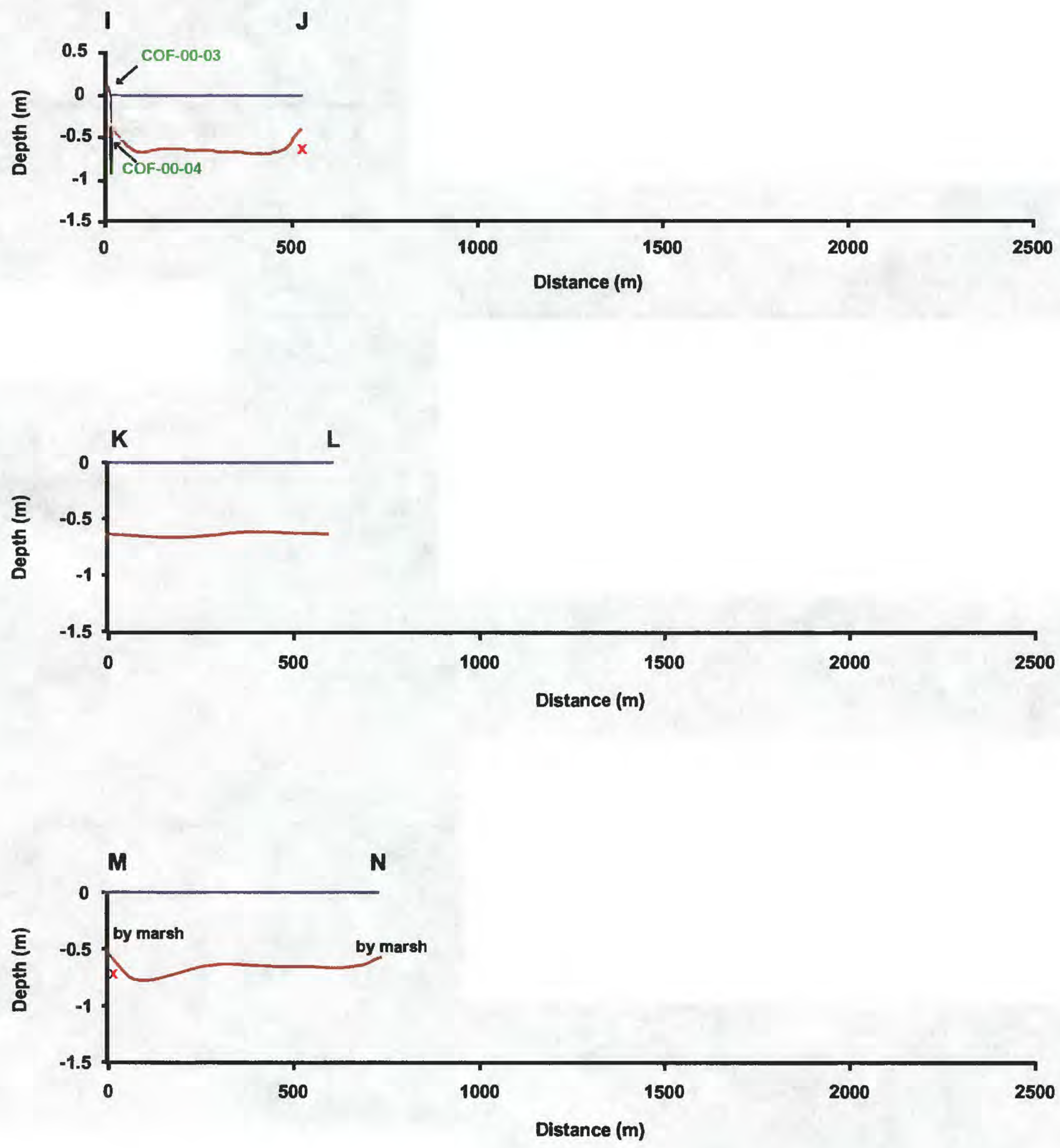


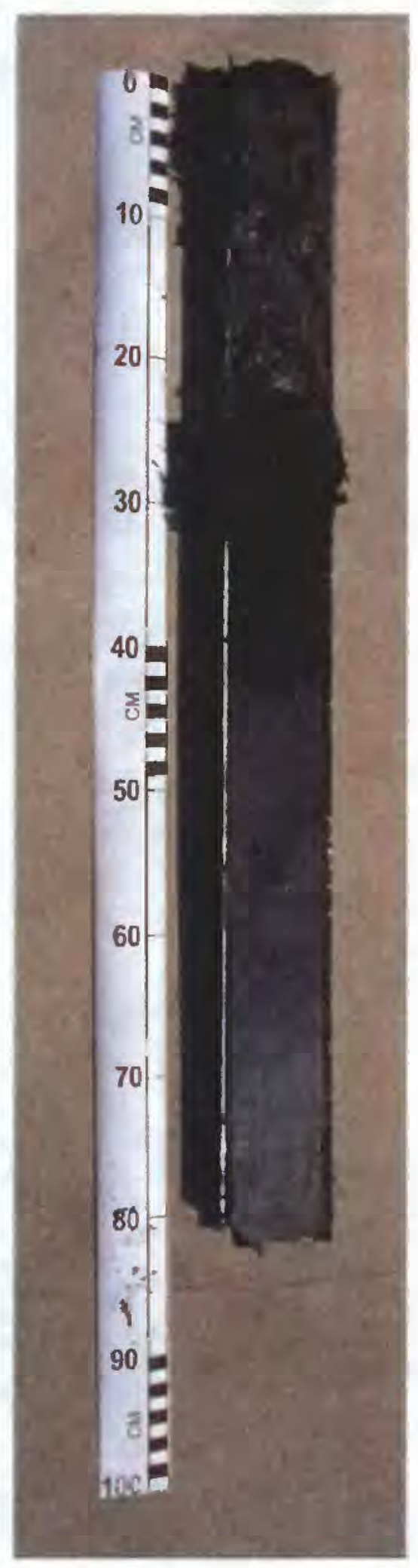

\section{Core BH-00-01}

Location: Port Neches, Orange County, TX

Latitude N30 01 '15.28"

Water depth $0.06 \mathrm{~m}$

Date obtained 06/16/2000

Longitude W93 $57^{\prime} 23.48^{\prime \prime}$

Length recovered $0.81 \mathrm{~m}$

Date described 08/18/00

$0-10 \mathrm{~cm}$

Organic Mnd Olive gray (5Y3/2)

Root mat: $5 \% 1 \mathrm{~cm}, 40 \% 1-2 \mathrm{~mm}, 55 \%$ fibrous with mud holding roots together, roots are $v$. dense at top, section becomes less rooted with increased mud toward bottom of section

* distinct contact

$10-24 \mathrm{~cm}$

Organic Mud Medium dark gray (N4)

$\sim 1 / 4$ to $1 / 3$ the number of roots as above section

Roots: $35 \% 1-2 \mathrm{~mm}, 65 \%$ fibrous, roots are not dense and mud is water saturated, root density decreases and $\%$ mud increases toward bottom of section

* distinct contact

$24-34 \mathrm{~cm}$

Organic Mnd Olive black (5Y2/1)

Root mat: $60 \% 2-3 \mathrm{~cm}, 20 \% 1-2 \mathrm{~mm}$, $20 \%$ fibrous with mud holding roots together

* distinct contact

$34-53 \mathrm{~cm}$

Organic Mud Brownish black (5YR 2/1) to black (N1)

Compressed, spongy, organic material with $1 \% \leq 0.5 \mathrm{~mm}$, $99 \%$ fibrous

Visible roots, spongy texture decreases and \% mud increases toward bottom

* gradational contact

$53-73 \mathrm{~cm} \quad$ Mud Grayish black (N2) and med dark gray (N4) to med. light gray (N6) $2 \mathrm{~cm}$ root trace (or burrow) protrudes through to $57 \mathrm{~cm}$ and resembles organic spongy texture of above section.

$57-68.5 \mathrm{~cm}$ and around above feature, common mottled (some grayish black (N2)) mud- bioturbation

Section becomes slightly more mottled and lighter in color toward bottom

Roots: $\leq 0.5 \mathrm{~mm}$ (random)

* gradational contact

* at $73 \mathrm{~cm} ~ 1 \mathrm{~mm}$ in thickness - light olive (10Y5/4) oxidized layer (looks like algal mat)

Mnd Med. gray (N5) and med. light gray (N6)

Below light olive layer there is a small lens of light olive (10YR 5/4) organic remains on left side of core

Color darkens and becomes more olive gray (5Y 4/1) toward bottom 
APPENDIX B: CORE DESCRIPTIONS 


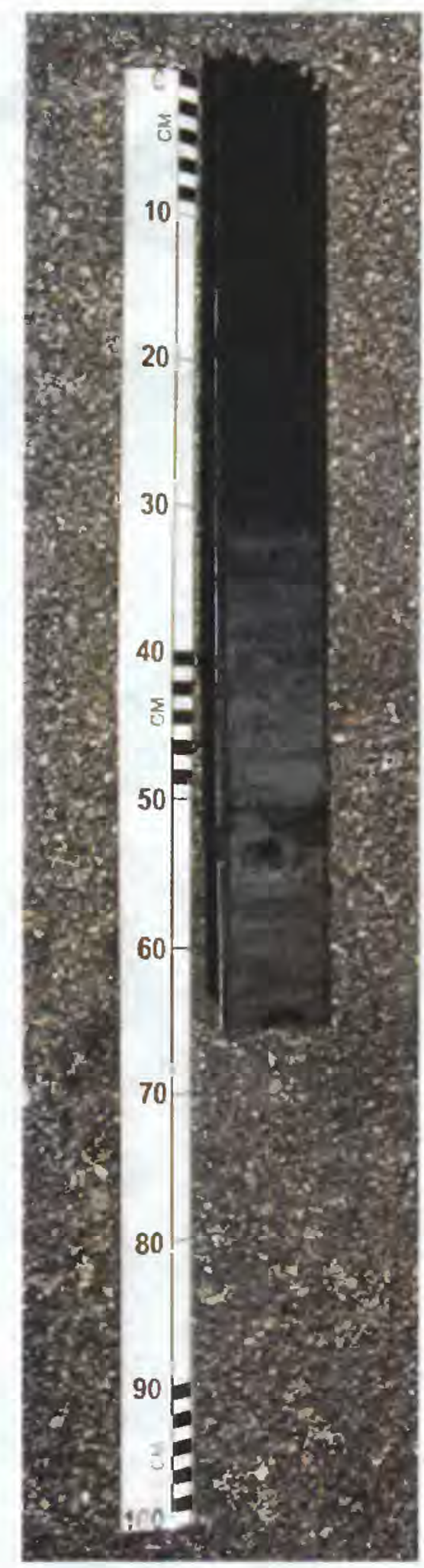

\section{Core BH-00-02}

Location: Port Neches, Orange County, TX

Latitude N30 $01^{\prime} 24.94^{\prime \prime}$

Water depth $0.89 \mathrm{~m}$

Date obtained 06/16/2000

Longitude W93 ${ }^{\circ} 57^{\prime} 14.05^{\prime \prime}$

Length recovered $0.65 \mathrm{~m}$

Date described 08/18/00

$0-33 \mathrm{~cm} \quad$ Organic Mud Brownish black (5YR2/1)

Top of section - organic spongy material

Roots: $5 \% 0.5 \mathrm{~mm}, 95 \%$ fibrous

Middle to bottom of section - fibrous roots present but not common

Spongy texture decreases and \% mud increases with depth

Some slight mottling at $27 \mathrm{~cm}$ (med. gray (N5))

* gradational contact

$33-49 \mathrm{~cm}$ Mud Med. dark gray (N4) to med. light gray (N6)

Abundant mottling disseminated, mottling (dark gray (N3)) may represent original laminations

Section becomes lighter down core

Roots: $2 \% 0.5 \mathrm{~mm}, 98 \%$ fibrous (random)

* gradational contact

$49-55 \mathrm{~cm}$ Mud Med. gray (N5) to med. light gray (N6)

Looks just like above section except large patches of oxidized organic material - light olive brown (5Y5/6) and mod. olive brown (5Y4/4) with dusky yellowish green (10GY3/2) and light olive (10Y5/4) - pelletlike features

* gradational contact - load feature?

$55-65 \mathrm{~cm}$

Mud Olive gray (5Y 4/1)

Slight organic mottling and more uniform brown color $61 \mathrm{~cm}$ - small lens of v. fine-grained sand 


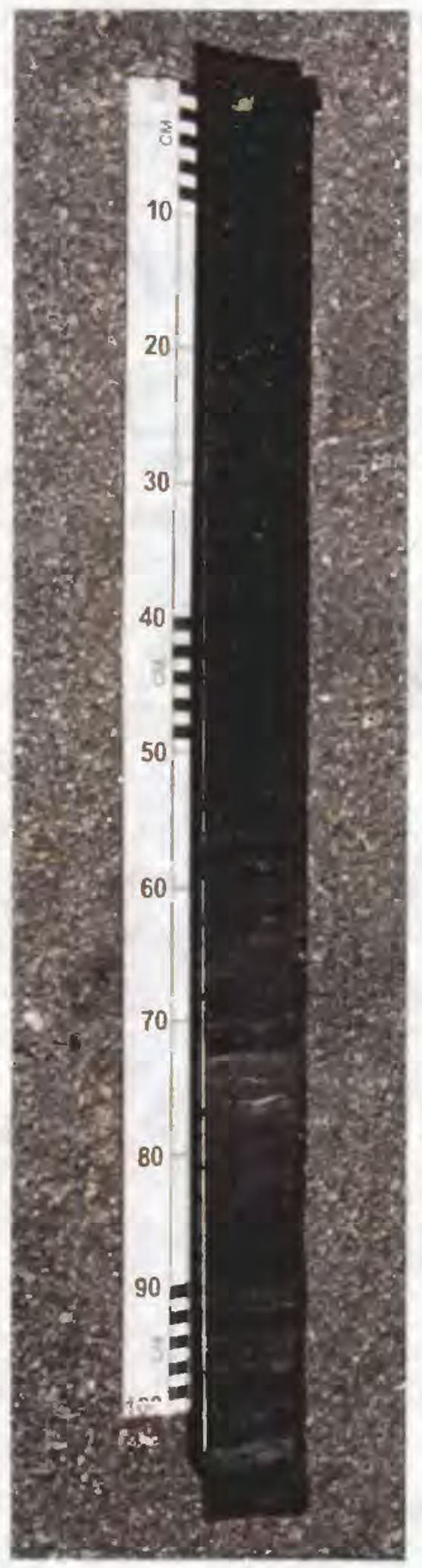

\section{Core BH-00-03}

Location: Port Neches, Orange County, TX Latitude $\mathrm{N} 30^{\circ} 02^{\prime} 41.81^{\prime \prime}$

Longitude W93 $57^{\prime} 27.49^{\prime \prime}$

Water depth $0.87 \mathrm{~m}$

Date obtained 06/16/2000

Length recovered $105 \mathrm{~m}$

Date described 08/18/00

$0-59 \mathrm{~cm}$

Organic Mud Olive black (5Y 2/1)

At top -1 valve of Rangia cuneata either stained greenish brown or chiton layer (freshwater) slightly leached

Roots: $50 \% 1-3 \mathrm{~mm}, 50 \%$ fibrous

V. hydrous at top with an increase in mud and more compacted toward bottom

$55.5 \mathrm{~cm}$ pale olive (10Y 6.2) mottling, closer to left side Less of above roots visible toward bottom, bottom becoming more spongy

* gradational contact into laminations

$59-80 \mathrm{~cm}$

Mud Grayish black (N2) with olive black (5Y 2/1) and olive gray (5Y 4/1) with med. gray (N5)

Alternating light and dark color laminations with organic mottling of lighter layers

Roots: fibrous (random), with a few $1 \mathrm{~mm}$ roots at $61 \mathrm{~cm}, 74-77 \mathrm{~cm}$ (rt side)

* gradational contact

$80-88 \mathrm{~cm}$

Organic Mud Olive black (5Y 2/1)

Organic spongy texture

*somewhat distinct contact

$88-90 \mathrm{~cm} \quad$ Mud Grayish black (N2) with olive black (5Y 2/1) and olive gray (5Y 4/1) with med. gray (N5)

Laminations not completely continuous left to right

* gradational contact

90-105cm Organic Mud Olive black (5Y 2/1)

Organic spongy texture 


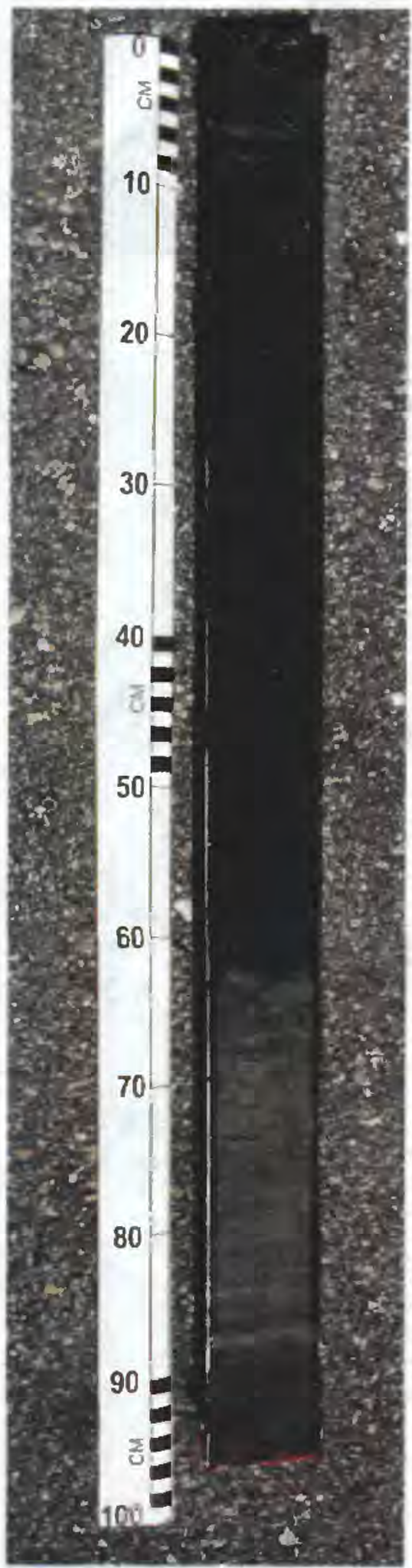

\section{Core BH-00-04}

Location: Port Neches, Orange County, TX

Latitude N30 $02^{\prime} 42.73^{\prime \prime}$

Water depth $0.46 \mathrm{~m}$

Longitude W93 $55^{\prime} 17.72^{\prime \prime}$

Date obtained 06/16/2000

Length recovered $0.93 \mathrm{~m}$

Date described 08/15/00

0-2.5cm Mud Greenish black (5GY 2/1)

V. hydrous, no noticeable roots

distinct contact

2.5-6cm Sandy Mud Olive gray (5Y 4/1 - dark) with med dark gray (N4) Hydrous, no noticeable roots

* distinct contact

$6-23 \mathrm{~cm}$

Organic Mud Olive black (5Y 2/1)

Root mat: $2 \% 1 \mathrm{~cm}, 80 \% 1-3 \mathrm{~cm}, 18 \%$ fibrous with mud holding roots together

* distinct contact

$23-37 \mathrm{~cm}$

Organic Mud Olive black (5Y 2/1)

Much less rooted and increase in \% mud than above section Spongy texture

Roots: $2 \% 0.2 \mathrm{~mm}-95 \%$ fibrous

* distinct contact

$37-43 \mathrm{~cm}$

Organic Mud Brownish black (5YR 2/1) with grayish black (N2) Looks similar to above section but darker and more compact Still has spongy texture

* distinct contact

$43-61 \mathrm{~cm}$

Organic Mud Brownish black (5YR 2/1) with grayish black (N2) No spongy texture - more compact $49-51 \mathrm{~cm}$ mottled (light olive brown (5Y 5/6) area on right side Mottling also present toward bottom of section (olive gray ( 5 Y $3 / 2)$ ) Roots: $\leq 0.2 \mathrm{~mm}$ (random)

* distinct contact - root penetration, jagged edges

$61-87.5 \mathrm{~cm}$

Mud Light olive brown (5Y 5/6) to light olive grayish brown (5Y 5/4) Oxidized paleosol - Deweyville $63-68.5 \mathrm{~cm}$ and $71.5 \mathrm{~cm}$ mottling - organic - original laminations? Section lightens and mottling decreases down core Roots: fibrous (random)

* distinct contact

$87.5-93 \mathrm{~cm}$

Muddy Sand Light olive grayish brown (5Y 5/4)

Oxidized fluvial sand - Deweyville

V. little mud, organic mottling (light olive brown (5Y 5/6) with grayish black (N2)

Roots: one, $1 \mathrm{~mm}$ root on right side of core at $92 \mathrm{~cm}$ 


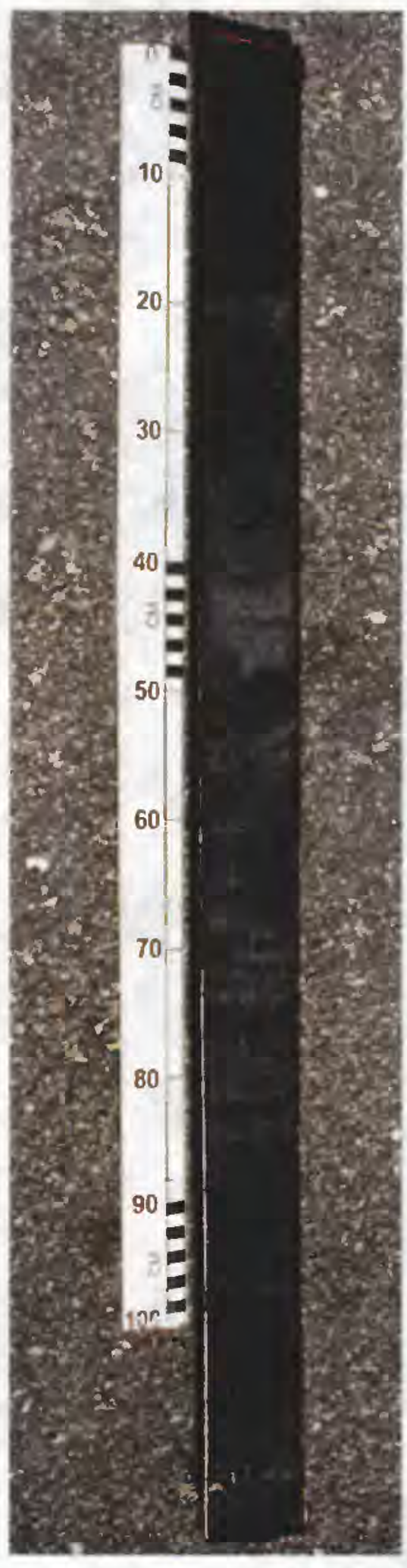

\section{Core BH-00-05}

Location: Port Neches, Orange County, TX

Latitude N30 $01^{\prime} 02.92^{\prime \prime}$

Water depth $0.63 \mathrm{~m}$

Longitude W93 $54^{\circ} 4507^{\prime \prime}$

Date obtained 06/16/2000

Length recovered $1.15 \mathrm{~m}$

Date described 08/15/00

$0-15 \mathrm{~cm}$

Organic Mud Olive black (5Y 2/1)

Root mat: one large $1 \mathrm{~cm}$ vertical root almost fully intact, $20 \% 1-2 \mathrm{~mm}, 79 \%$ fibrous

Generally unconsolidated, becoming more compact with increasing $\%$ mud toward bottom of section

* gradational contact

$15-19 \mathrm{~cm}$

Mud Grayish black (N2)

Roots: $5 \% 1 \mathrm{~mm}, 95 \%$ fibrous

* gradational contact

$19-21.5 \mathrm{~cm}$

Mud Pale olive (10Y6/2)

Roots: $5 \% \leq 0.5 \mathrm{~mm}, 95 \%$ fibrous (random)

* distinct contact

$21.5-32 \mathrm{~cm}$

Mud Grayish black (N2)

Spongy texture at top, decreasing toward bottom of section Med. light gray (N6) mottling toward bottom of section Roots: fibrous

* gradational contact

$32-42 \mathrm{~cm}$

Mud Mottled between med. light gray (N6) and med. dark gray (N4) Primarily med. dark gray with distinct smaller areas of med. light gray Roots: $5 \% \leq 1 \mathrm{~mm}, 95 \%$ fibrous (random)

* distinct contact

$42-48 \mathrm{~cm}$

Mud Med. light gray (N6) to light olive gray (5Y6/1) Med. light gray grades into light olive gray downcore 44-45cm - med. dark gray (N4) laminae Load structure at bottom of section (or just drag?)

* distinct contact

$48-66.5$

Mud Dark gray (N3) with med. gray (N5)

Mottled throughout with areas of med. dark gray (N4) and light olive gray (5Y6/1)

Roots: $\leq 1 \mathrm{~mm}$ (random)

* gradational contact

$66.5-84 \mathrm{~cm}$ Mud Dark gray (N3) with med. gray (N5) Alternating dark and med. gray $1-2 \mathrm{~mm}$ laminae Mottling within layers

*distinct contact

$84-115 \mathrm{~cm}$

Organic Mnd Brownish black (5YR2/1)

Spongy texture, $1 \% 1 \mathrm{~mm}, 99 \%$ fibrous 


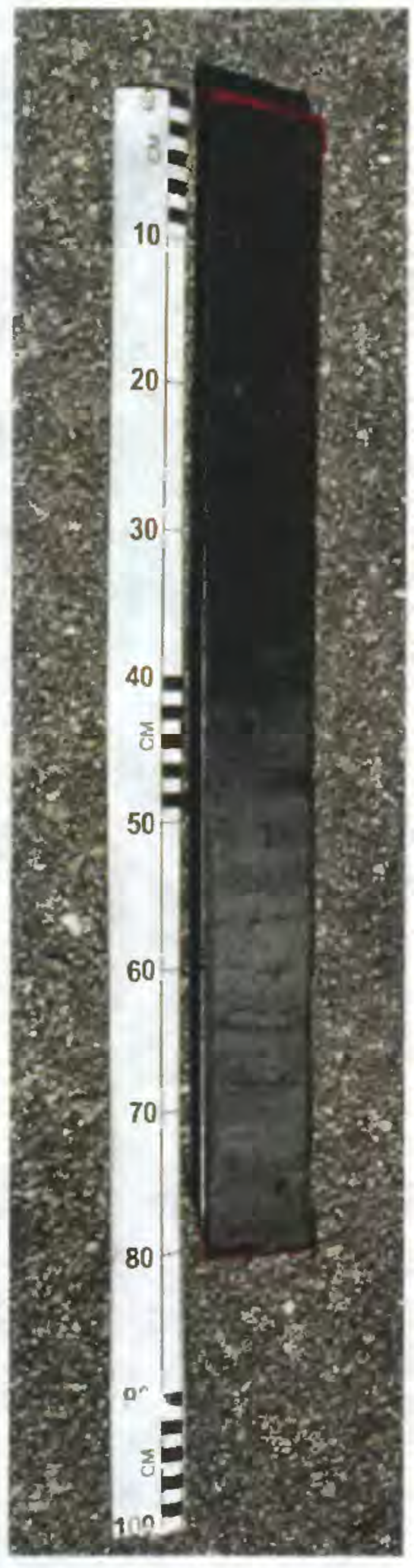

Core BH-00-06

Location: Port Neches, Orange County, TX

Latitude N30 $00^{\prime} 50.79^{\prime \prime}$

Longitude W93 ${ }^{\circ} 56^{\prime} 46.69^{\prime \prime}$

Water depth $0.53 \mathrm{~m}$

Date obtained 06/16/2000

Length recovered $0.77 \mathrm{~m}$

Date described 08/18/00

$0-12 \mathrm{~cm}$

Organic Mud Brownish black (5YR2/1)

Root mat: $10 \% 1.5-2 \mathrm{~cm}, 20 \% 1-2 \mathrm{~mm}, 70 \%<1 \mathrm{~mm}$-fibrous

$8-12 \mathrm{~cm}$ - right side of core differs from above and has $\leq 0.5 \mathrm{~mm}$-fibrous roots and spongy texture (which grades into section below)

* gradational contact

$12-41 \mathrm{~cm}$

Organic Mud Grayish black (N2) to med. light gray (N6)

Root density decreases and \% mud increases with depth

$12-29 \mathrm{~cm}$ - spongy texture, roots: $20 \% 1 \mathrm{~mm}$ and $80 \%$ fibrous $29-39 \mathrm{~cm}$ - decrease in spongy texture, roots: $5 \% \leq 1 \mathrm{~mm}$ and $95 \%$ fibrous (random) and increase in lightness with some organic mottling toward bottom

* gradational contact

$41-77 \mathrm{~cm}$

Mud Med. light gray (N6) and med. dark gray (N4) Abundant mottling but decreasing with depth $51-52 \mathrm{~cm}$ mottling resembles laminations Roots: $<1 \mathrm{~mm}$ (random)

$64-65 \mathrm{~cm}$ oxidized organic lens grayish green (10GY 5/2) (v. small pelletlike)

$70-77 \mathrm{~cm}$ color changes gradually to a darker shade of olive gray (5Y4/1) - more uniform brown color, $1-2 \mathrm{~mm}$ roots (v. random) 


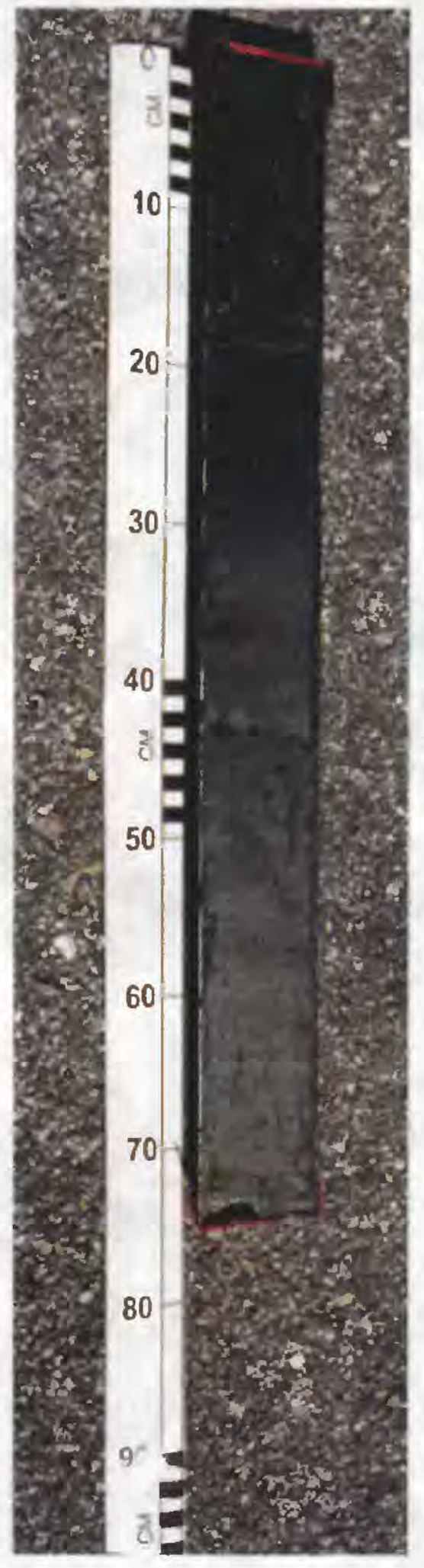

\section{Core COF-00-01}

Location: Caplen Oil Field, Galveston County, TX Latitude N29 $29^{\prime} 41.05^{\prime \prime}$

Longitude W94 $35^{\prime} 21.89^{\prime \prime}$

Water depth $0.13 \mathrm{~m}$

Length recovered $0.73 \mathrm{~m}$

Date obtained 06/18/2000

Date described 08/21/00

$0-2 \mathrm{~cm}$

Mud Olive gray (5Y3/2)

Mostly hydrous mud

Roots: $10 \% 1 \mathrm{~mm}, 90 \%$ fibrous (random)

* gradational contact

$2-17 \mathrm{~cm}$

Organic Mud Olive gray (5Y3/2) to greenish black (5GY 2/1) with depth Less hydrous than above and slightly noncohesive Roots: $20 \% 1 \mathrm{~mm}, 80 \%<1 \mathrm{~mm}$ - fibrous

* gradational contact

$17-27 \mathrm{~cm}$

Mud Dark gray (N3)

Some med. light gray (N6) and grayish black (N2) mottling More mud present and more compacted than above Spongy texture at top which decreases toward bottom Roots: $15 \%<1 \mathrm{~mm}, 85 \%$ fibrous

* gradational contact

$27-52 \mathrm{~cm} \quad$ Mud Medium gray (N5) to med. light gray (N6) and greenish gray (5GY 6/1) with depth

Disseminated grayish black (N2) mottling except a horizontal feature (lamination) $\sim 42 \mathrm{~cm}$ which is below a few $0.5-1 \mathrm{~cm}$ diameter lenses of mottled v. fine-grained sandy mud $40-41 \mathrm{~cm}$

Roots: $\leq 1 \mathrm{~mm}$ (random to common)

* distinct contact

$52-73 \mathrm{~cm}$

Sandy mud Greenish gray (5GY 6/1)

Drag of upper section present along rt side of core $51-69 \mathrm{~cm}$ Iron-stained organic remains - Moderately light brown (5YR 4/5) and moderate brown (5YR 3/4) $68.5-73 \mathrm{~cm}$ Roots: $\leq 1 \mathrm{~mm}$ (random to common) 


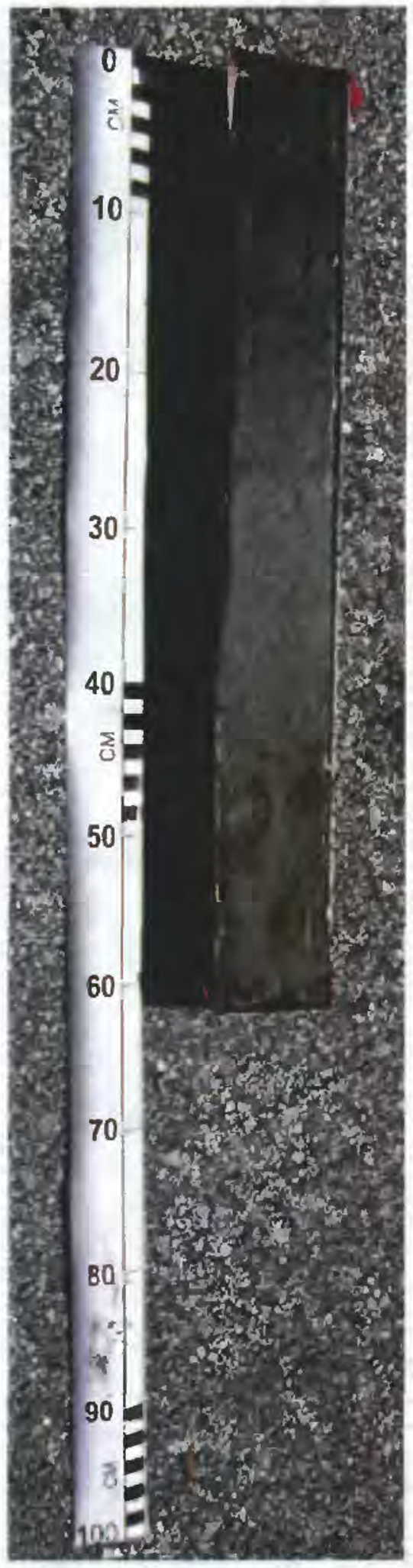

\section{Core COF-00-02}

Location: Caplen Oil Field, Galveston County, TX Latitude N29 $29^{\prime} 40.98^{\prime \prime}$

Water depth $0.44 \mathrm{~m}$

Date obtained 06/18/2000

Longitude W94 $355^{\prime} 21.77^{\prime \prime}$

Length recovered $0.60 \mathrm{~m}$

Date described 08/22/00

0-6cm Sandy Mnd Olive gray (5Y4/1)

V. little sand, somewhat hydrous

Roots: few fibrous (random)

* gradational contact

$6-25.5 \mathrm{~cm}$

Mud Med. dark gray (N4) to med. greenish gray (5GY 5/1) Common organic mottling

Dark gray (N3) layer of organic mud $6-8 \mathrm{~cm}$

Roots: $\leq 1 \mathrm{~mm}$ roots (random)

* gradational contact

$25.5-35 \mathrm{~cm}$

Sandy Mud Med. - dark greenish gray (5GY 5/1-4/1)

V. little $v$. fine-grained sand, v. little organic mottling Roots: $\leq 0.5 \mathrm{~mm}$ (random)

* gradational contact

$35-60 \mathrm{~cm}$

Sandy mud Med greenish gray (5GY 5/1)

Iron-stained organic remains - Moderately light

brown (5YR 4/5) and moderate brown (5YR 3/4)

mottling disseminated, but increases between $43-56 \mathrm{~cm}$ Roots: $\leq 0.5 \mathrm{~mm}$ (random) 


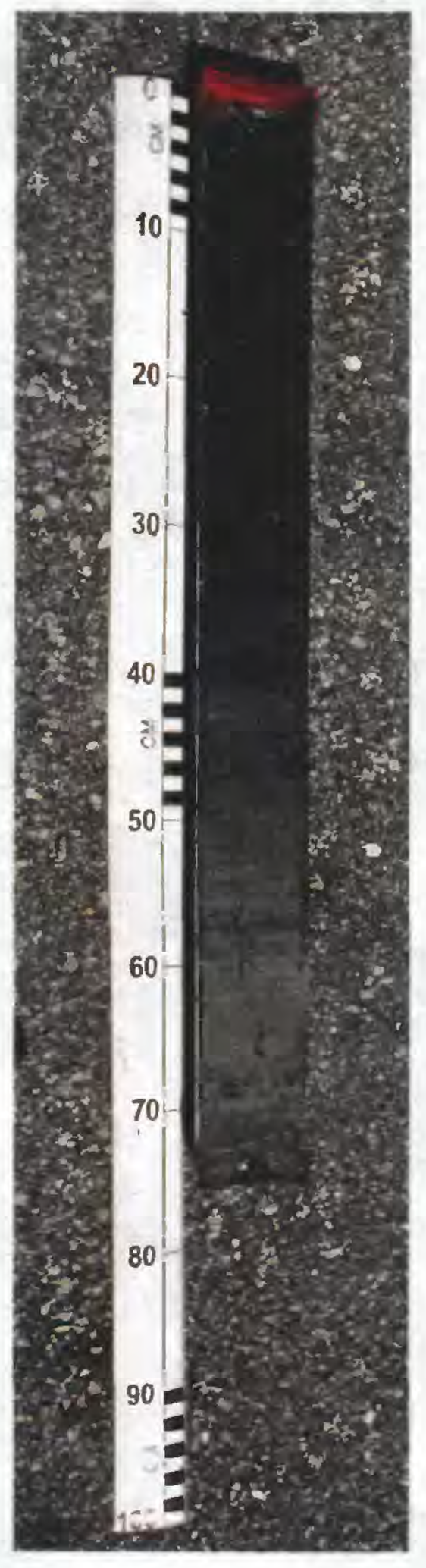

\section{Core COF-00-03}

Location: Caplen Oil Field, Galveston County, TX Latitude $\mathrm{N}^{2} 9^{\circ} 30^{\prime} 48.85^{\prime \prime}$

Longitude W94'34'23.20"

Water depth $0.04 \mathrm{~m}$

Date obtained 06/19/2000

Length recovered $0.71 \mathrm{~m}$

Date described 08/22/00

$0-20 \mathrm{~cm}$

Organic Mud Olive black (5Y2/1)

Root mat: $40 \%$ 1mm, $60 \%$ fibrous

Section becomes more compact (spongy) toward bottom

* distinct contact

$20-37.5 \mathrm{~cm}$

Mud Dark gray (N3) to med. dark gray (N4) with depth Section becomes lighter toward bottom with light greenish gray (5GY 6/1) mottling and organic mottling - grayish black (N2)

More mottled and less rooted than above section

Roots: $\leq 10 \% 1 \mathrm{~mm}, 90 \%$ fibrous (random, but more concentrated toward top of section)

* gradational contact

$37.5-45 \mathrm{~cm}$

Mud Med. dark gray (N4)

Matrix is med. dark gray (N4) with abundant light greenish gray (5GY 6/1) mottling, v. little organic mottling Roots: $\leq 1 \mathrm{~mm}$ (random)

* gradational contact

$45-57 \mathrm{~cm}$

Sandy Mud Medium gray (N5) and light greenish gray (5GY 6/1)

Mottling with some iron staining, moderately light brown (5YR 4/5) and moderate brown (5YR 3/4) mottling concentrated between $44-49 \mathrm{~cm}$

Grayish black (N2) organic mottling disseminated with a larger vertical patch $53-55 \mathrm{~cm}$

V. fine-grained sand

Roots: $\leq 1 \mathrm{~mm}$ (random)

* gradational contact

$57-71 \mathrm{~cm}$

Sandy Mud Light olive gray (5GY 6/1) and light greenish gray (5GY 6/1) Less mottling and more iron staining than $45-57 \mathrm{~cm}$

Iron-stained organic remains - moderately light brown (5YR 4/5) and moderate brown (5YR 3/4) mottling concentrated toward bottom of section - although $0.5 \mathrm{~mm}$ diameter mottles slightly disseminated

V. fine-grained sand

Roots: $\leq 1 \mathrm{~mm}$ (random)

* gradational contact (except right side)

$71-73 \mathrm{~cm}$

Mud and Sand Medium olive gray (5Y 5/1)

Left side of core is sandy mud, right side is muddy sand 


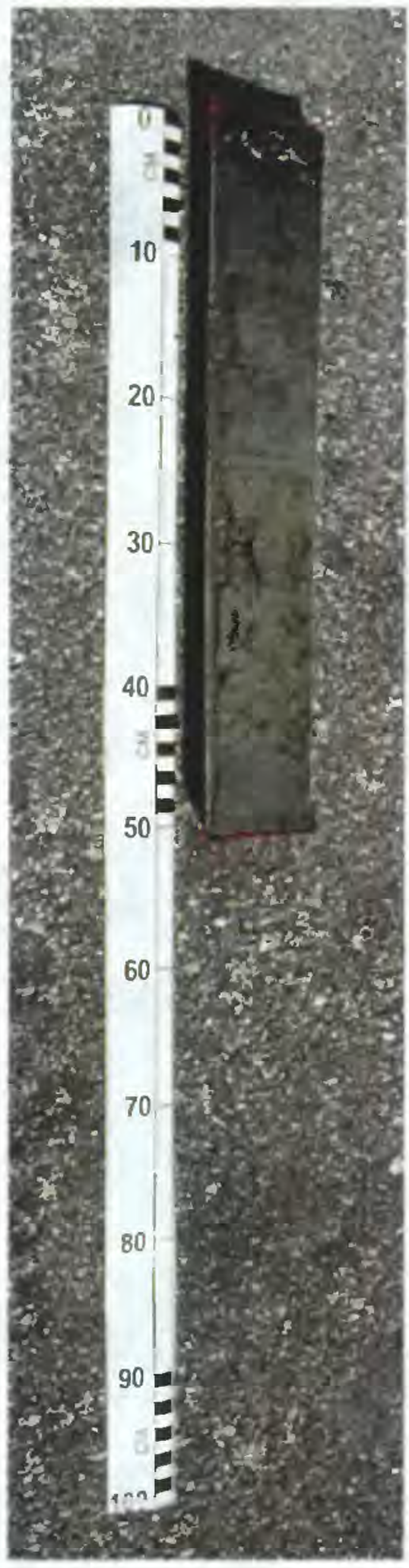

Core COF-00-04

Location: Caplen Oil Field, Galveston County, TX Latitude $\mathrm{N} 29^{\circ} 30^{\prime} 48.88^{\prime \prime}$

Longitude W94 $34^{\prime} 23.20^{\prime \prime}$

Water depth $0.43 \mathrm{~m}$

Length recovered $0.49 \mathrm{~m}$

Date obtained 06/19/2000

Date described 08/15/00

0-4cm Sandy Mnd Dark gray (N3)

Shell fragments and whole bivalve valves

(black, brown, opalescent)

Somewhat noncohesive

* distinct contact

4-10cm Mud Dark gray (N3) to medium gray (N5)

Grayish black (N2) organic mottling disseminated

Roots: $\leq 1 \mathrm{~mm}$ (random)

* gradational contact

$10-22 \mathrm{~cm}$

Sandy Mud Medium gray (N5) and light greenish gray (5GY 6/1)

Dark gray (N3) mottling - specks/lines (laminations that were bioturbated)

Iron-stained organic remains - Moderately light brown (5YR 4/5) and moderate

brown (5YR 3/4) mottling

Lines and areas of mottling are typically vertical

V. fine-grained sand

Roots: $\leq 1 \mathrm{~mm}$ found within $8-10 \mathrm{~cm}, 11-14 \mathrm{~cm}$ with some random

* gradational contact

$22-46 \mathrm{~cm}$

Sandy Mnd Medium gray (N5) and light greenish gray (5GY 6/1) Similar to $10-22 \mathrm{~cm}$, but decreased mottling and increased iron staining

Limes and areas of mottling are typically vertical

Roots: $\leq \mathrm{Imm}$ found within $24-25 \mathrm{~cm}$ with some random

* gradational contact

$46-49 \mathrm{~cm}$

Mnd and Sand Olive gray (5Y 4/1) and medium gray (N5)

$1 / 2$ core (left) is muddy sand lens (light olive gray (5Y5/2))

$1 / 2$ core (right) is sandy mud lens (med. dark gray (N4)) - however, mud does extend under sand lens at $1 / 4 \mathrm{~cm}$ from bottom of core 
